\title{
Phylogenetic analysis of selected representatives of the genus Erica based on the genes encoding the DNA-dependent RNA polymerase I
}

\author{
Angelika Maria Gomolińska ${ }^{1 *}$, Monika Szczecińska ${ }^{1}$, Jakub Sawicki ${ }^{1,2}$, \\ Katarzyna Krawczyk ${ }^{1}$ \& Piotr Szkudlarz ${ }^{3}$
}

\begin{abstract}
${ }^{1}$ Department of Botany and Nature Protection, University of Warmia and Mazury in Olsztyn, Plac Łódzki 1, 10-727 Olsztyn, Poland ${ }^{2}$ Department of Biology and Ecology, University of Ostrava, Chittusiho 10, Ostrava, Czech Republic ${ }^{3}$ Department of Plant Taxonomy, Adam Mickiewicz University, Umultowska 89, 61-614 Poznań, Poland *corresponding author (e-mail: angelika.gomolinska@uwm.edu.pl)
\end{abstract}

\begin{abstract}
The rpo genes are characterized by rapidly-evolving sequences. They encode subunits of plastid-encoded (PEP) polymerase (rpoA, rpoB, rpo $\mathrm{C} 1$ and $r p o \mathrm{C} 2)$. This polymerase is one of the most important enzymes in the chloroplasts. The primary aim of the research was to study the rate of molecular evolution in the rpo genes and to estimate these genes as phylogenetic markers based on the example of the genus Erica (Ericaceae). The tested rpo genes demonstrated similarities on multiple levels, for example: phylogenetic informativeness, variation level, intragenic mutation rates and the effect of intragenic mutations on the properties of encoded peptides. This study did not confirm that the analyzed rpo genes are reliable markers and may be helpful in understanding phylogenetic relationships between species that belong to the same genus. The rpoC2 gene was found to be a most useful phylogenetic marker in the Erica genus, while rpoC1 was found to be the least promising gene.
\end{abstract}

Key words: Ericaceae, molecular evolution, phylogenetic informativeness, phylogenetic signal, rpo

\section{Introduction}

Chloroplasts have a unique hybrid transcription system composed of the remaining prokaryotic components, such as prokaryotic RNA polymerase, and nucleus-encoded eukaryotic components. Genes regulating gene expression in chloroplasts are encoded in the nucleus. Chloroplast DNA (CpDNA) in terrestrial plants consists of nearly 100 genes, the majority of which reside in transcription units derived from bacterial operons (Chotewutmontri et al. 2016). RNAP - a bacterial multi-subunit - is composed of the core rpo complex that recognizes promoter sequences. The bacterial-type RNAP, called plastid-encoded plastid RNAP (PEP), which occurs in chloroplasts, shows a functional similarity to bacterial RNAP (Korczak et al. 2004; Yagi et al. 2014). The transcription of plastid-encoded genes in plants is arbitrated by two RNA polymerases of different phylogenetic origin: PEP of endosymbiotic origin (a plastid-encoded RNA polymerase - encoded by plastid rpo genes) and a nuclear-encoded RNA polymerase - NEP (of nuclear origin). PEP and NEP transcribe many of the same genes using different promoters. Numerous plastid genes and operons have at least one promoter each for PEP and NEP. The subgroup of plastid genes, including photosystem I and II genes, is transcribed from PEP promoters only, while in some plant species, genes are transcribed entirely by NEP (Maddison et al. 2006; Blazier et al. 2016). By contrast, all genes for chloroplast signal factors were transferred to the nuclear genome, while genes for core subunits are typically retained in the chloroplast genome as $r p o \mathrm{~A}, r p o \mathrm{~B}, r p o \mathrm{C} 1$ and $r p o \mathrm{C} 2$. In the present study, the group of rpo genes $(r p o \mathrm{~A}, r p o \mathrm{~B}, r p o \mathrm{C} 1$ and $r p o \mathrm{C} 2$ ) was analysed. These genes encode subunits of plastid-encoded polymerase (PEP) and are relatively 
fast-evolving sequences compared to other genes in the genome of plants (Serino et al. 1998; Nei \& Kumar 2000; Krawczyk \& Sawicki 2013). PEP contains four subunits: $\alpha$-encoded by rpoA, and the three largest PEP subunits $-\beta, \beta$, and $\beta$ ", which are encoded by rрo $\mathrm{B}, r p o \mathrm{C} 1$, and rpoC2 plastid genes, respectively. The rpo genes were used as markers of comparatively fast-evolving sequences of PEP polymerase in several phylogenetic studies (Allison et al. 1996; Petersen \& Seberg 1997; Korczak et al. 2004; Chelo et al. 2007; Logacheva et al. 2007). These studies indicated the suitability of the studied rpo genes for analyses at a high taxonomic rank (such as the division level) and also at the genus level. Single genes of the rpo group were used to study plant evolutionary history at the family and genus levels (Little \& Hallick 1988; Krause et al. 1998; Logacheva et al. 2007; Krawczyk \& Sawicki 2013) and in bacteria - at the genus level (Korczak et al. 2004; Chelo et al. 2007).

This study assessed the analyzed genes as phylogenetically-useful markers and analyzed the impact of substitutions that trigger changes in amino acids located in the encoded proteins. The subject of the study were representatives of the family Ericaceae. This family comprise about 4,100 species, many of them endemic and threatened, belonging to 126 genera (Schumann et al. 1992; Oliver 1993; Ojeda et al. 2015). Ericaceae includes shrubs and climbers that occupy acidic, nutrient-poor habitats, often containing high levels of heavy metals. In response to such conditions, Ericaceae species form symbiosis with mycorrhizal fungi. This type of symbiosis is called ericoid mycorrhiza and ensures successful colonization of acid and poor soils (Bruzone et al. 2015). Ericaceae range all over the world, except central Greenland, parts of the high Arctic, continental Antarctica, and northern and central Australia. Erica is one of the two largest genera in the family, next to Rhododendron, and is widespread in Asia (Glen 2002; Linder 2003; Stevens et al. 2004; McGuire \& Kron 2005). It comprises about 860 species of flowering plants. Erica species are generally low shrubs (20-140 cm of high), although sometimes higher-like E. arborea that reaches up to $7 \mathrm{~m}$ in height. All Erica species are evergreen, with needle-like leaves. The region most diverse in the Erica species is the Cape Floristic Region (CFR). With more than 700 species and a high level of endemism, Erica represents the epitome of plant biodiversity. This genus shows a pattern of high species concentration in fynbos; a fire-prone, heathlandlike vegetation and includes re-sprouter and seeder species, like most fynbos woody taxa (Linder 2003; Gillespie \& Kron 2010; Yoichi \& Tomaru 2014; Ojeda et al. 2015). Erica is taxonomically well-documented, but still little is known about species-level relationships. The systematic position of Erica has been addressed in various studies of phylogenetic relationships within Ericaceae (Gillespie \& Kron 2010; Pirie et al. 2011; Yoichi \& Tomaru 2014). Phylogenetic relationships among species of the genus Erica were examined to find whether this genus originates from Africa or Europe. The first phylogenetic study of Erica was based on 3 regions of DNA, 2 sequences encoded by chloroplasts $a t p \mathrm{~B}-r b c \mathrm{~L}$ spacer and partial $m a t \mathrm{~K}$, and 1 from nuclear genome (internal transcribed spacer region of nuclear ribosomal DNA, ITS) (McGuire \& Kron 2005). The second major phylogenetic analysis of Erica, using only ITS sequences, included as many as 379 species. It demonstrably shows relatively low variation in nrITS sequences in the broad sample of ca. $45 \%$ species assigned to Erica. In both cases, the conducted analyses did not support the subgeneric division of the genus Erica (Pirie et al. 2011). The main goal of this study was to determine the usefulness of tested genes encoding a DNA-dependent RNA polymerase I in phylogenetic analyses of selected representatives of the genus Erica. Thus far, no studies have been published on chloroplast genes, particularly the rpo genes, in this genus.

\section{Material and methods}

\subsection{Plant material}

The study material included 50 Erica species that represented the following 5 subgenera: Syringodea (18 species), Euerica (17), Chlamydanthe (7), Plastoma (4) and Stellanthe (1). Different subgenera were represented by different numbers of species, because the number of representatives was matched to the species richness within the studied subgenera. All examined species are presented in Table 1. The classification of the genus is used according to the division proposed by Bentham (1839), modified by Hansen (1950) and supplemented by Oliver (2000). The nomenclature was adopted from Oliver (Oliver 1993; Oliver et al. 2003). Not all tested species provided the final results. For 9 tested species, the results of sequencing were not obtained. Thus the presented data relate to 41 species.

Vaccinum macrocarpon, Chamaedaphne calyculata and Arbutus unedo were incorporated into the study as an outgroup. Data for those three species were used as an outgroup, because they are closely related to the Erica genus and belong to one family Ericaceae. For those species, the entire chloroplast genome sequences were developed and they are available in the NCBI database. The samples were collected by the authors or other scientists during field research. Specimen vouchers are deposited in the herbarium POZ (Department of Plant Taxonomy, Adam Mickiewicz University in Poznań). The origin of analyzed species and collectors of samples are presented in Table 1. 


\subsection{Laboratory procedures and sequence alignment}

Leaves of representatives of the genus Erica were grated in a Mini-Beadbeater-1 tissue disruptor. Isola- tion of the DNA material was performed using a Zymo Research kit (isolation kit ZR Plant/Seed DNA Kit). Isolated DNA was then used in the subsequent analyses. The DNA fragments of $r p o \mathrm{~A}, r p o \mathrm{C} 1$ and $r p o \mathrm{C} 2$ genes

Table 1. The list of tested species within the subgenera and sections of the genus Erica with localities

\begin{tabular}{|c|c|c|c|c|}
\hline Genus & Subgenus & Section & Species & Locality / collectors \\
\hline \multirow[t]{46}{*}{ Erica } & \multirow[t]{18}{*}{ Syringodea } & \multirow[t]{5}{*}{ Gigandra } & Erica coccinea & RSA, Cape Aguhlas / SWO \\
\hline & & & \multirow{4}{*}{$\begin{array}{l}\text { Erica plukenetii } \\
\text { (4 samples) }\end{array}$} & Bottelary/SWO \\
\hline & & & & RSA, Cape Aguhlas/SWO \\
\hline & & & & RSA, Groot Gabel Kraal/SWO \\
\hline & & & & RSA, near Caledon /SWO \\
\hline & & \multirow[t]{6}{*}{ Pleurocallis } & Erica bauerii & RSA, Albertinia, W of town /SWO \\
\hline & & & Erica hibbertii & Theevaterkloof/SWO \\
\hline & & & Erica mammosa & RSA, Kleinmond /SWO \\
\hline & & & Erica regia & RSA, Cocsravier near Viljoenshof /SWO \\
\hline & & & Erica sessilliflora & RSA, Pilarkop, subalpine heathland /SWO \\
\hline & & & Erica vestita & RSA, Jonaskop, lower slopes/SWO \\
\hline & & \multirow[t]{6}{*}{ Evanthe } & Erica cruenta & RSA, near Caledon /SWO \\
\hline & & & Erica curviflora & RSA, Pilarkop, subalpine heathland /SWO \\
\hline & & & Erica discolor & RSA, Road to Kreisvalle /SWO \\
\hline & & & Erica patersonii & RSA, Betty’s Bay/SWO \\
\hline & & & \multirow{2}{*}{$\begin{array}{l}\text { Erica versicolor } \\
\text { ( } 2 \text { samples) }\end{array}$} & Bergfontein/SWO \\
\hline & & & & RSA, Langeberg, Tradous Pass /SWO \\
\hline & & Dasyanthes & Erica strigilifolia & RSA, Swartberg Pass /SWO \\
\hline & Stellanthe & Euryloma & Erica ampullaceae & RSA, Boskloof /SWO \\
\hline & \multirow[t]{17}{*}{ Euerica } & \multirow[t]{2}{*}{ Ephebus } & Erica caffra & RSA, Swartberg Pass /SWO \\
\hline & & & Erica hirtiflora & $\begin{array}{l}\text { RSA, Kirstenbosch, slope of the Tablle } \\
\text { Montain /SWO }\end{array}$ \\
\hline & & \multirow[t]{5}{*}{ Gypsocallis } & Erica nudiflora & Bainskloof/Witelsriver/SWO \\
\hline & & & Erica vagans & Spain, Navarra /S \\
\hline & & & Eirca multiflora & Spain, Estramadura /S \\
\hline & & & Erica globiceps & RSA, Boskloof /SWO \\
\hline & & & (2 samples) & RSA, Groot Hagelkraal /SWO \\
\hline & & Pachysa & Erica umbelliflora & Baviaansmountain/SWO \\
\hline & & \multirow[t]{2}{*}{ Chlorocodon } & Erica coarctata & Arieskraal, Palmiet River/SWO \\
\hline & & & Erica scoparia & Spain, Cap de Creus /S \\
\hline & & \multirow[t]{4}{*}{ Arsace } & Erica hispidula & Kouga/SWO \\
\hline & & & Erica zwartbergensis & RSA, Swartberg Pass /SWO \\
\hline & & & Erica arborea & Spain, Montradue /S \\
\hline & & & (2 samples) & Spain, Cap de Creus /S \\
\hline & & Eremocallis & Erica tetralix & Poland, Piaseczno near Węgliniec /S \\
\hline & & \multirow[t]{2}{*}{ Brachycallis } & \multirow{2}{*}{$\begin{array}{l}\text { Erica cinerea } \\
\text { (2 samples) }\end{array}$} & Spain, Navarra /S \\
\hline & & & & Scotland, Glen Cloe /S \\
\hline & \multirow[t]{6}{*}{ Chlamydanthe } & Geissostegia & $\begin{array}{l}\text { Erica imbricata } \\
\text { (2 samples) }\end{array}$ & $\begin{array}{l}\text { RSA, Elandskloof, Wolseley /SWO } \\
\text { RSA, Boskloof/SWO }\end{array}$ \\
\hline & & Eurystegia & Erica monsoniana & Cedarberg/SWO \\
\hline & & Adelopetalum & Erica nabea & Prince Alfreds Pass/SWO \\
\hline & & \multirow[t]{3}{*}{ Trigemma } & Erica baccans & $\begin{array}{l}\text { Ex. Hort Hermanus, Woodvine s.n. \& Hout } \\
\text { Bay /SWO }\end{array}$ \\
\hline & & & Erica plumigera & RSA, Kugel Bay, slope of a montain /SWO \\
\hline & & & Erica selaginifolia & Touwsberg/SWO \\
\hline & \multirow[t]{4}{*}{ Platystoma } & \multirow[t]{2}{*}{ Eurystoma } & Erica floccifera & Greyton /SWO \\
\hline & & & Erica pseudocalycina & Langeberg/SWO \\
\hline & & \multirow[t]{2}{*}{ Gamochlamys } & Erica melanthera & Tradouw Pass /SWO \\
\hline & & & Erica newdigateae & Smutskop/SWO \\
\hline
\end{tabular}

Explanations: sample collectors, S - Szkudlarz P., W - Wiland-Szymańska J., O - Oliver E. G. H. 
were amplified in a volume of $20 \mu \mathrm{L}$ containing $10 \mathrm{mM}$ Tris- $\mathrm{HCl}\left(\mathrm{pH} 8.3\right.$ at $25^{\circ} \mathrm{C}$ ), $50 \mathrm{mM} \mathrm{KCl}, 1,5 \mathrm{mM} \mathrm{MgCl} 2$, $1 \mu \mathrm{LBSA}, 200 \mu \mathrm{M}$ each dATP, dGTP, dCTP and dTTP, $1 \mu \mathrm{M}$ of each primer, one unit $(\mathrm{U})$ of Taq polymerase OpenEx (OpenExome) and 10-20 ng of the DNA template. The PCR reactions for $r p o A, r p o C 1$ and $r p o C 2$ genes were carried out under the following conditions: (1) initial denaturation $4 \mathrm{~min}$ at $94^{\circ} \mathrm{C}$; (2) denaturation $45 \mathrm{~s}$ at $94^{\circ} \mathrm{C}$; (3) annealing $1 \mathrm{~min}$ at $51^{\circ} \mathrm{C}$; (4) elongation $1.5 \mathrm{~min}$ at $72^{\circ} \mathrm{C}$; (5) final elongation $7 \mathrm{~min}$ at $72^{\circ} \mathrm{C}$. Stages 2-4 were repeated 40 times. Above conditions of $\mathrm{PCR}$ reactions gave weak amplification for $r p o \mathrm{~B}$ gene, so the conditions and buffer were changed. The DNA fragments of $r p o B$ genes were amplified in a volume

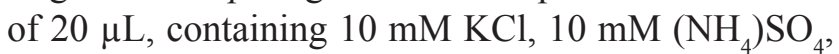
$20 \mathrm{mM}$ Tris- $\mathrm{HCl}\left(\mathrm{pH} 8.5\right.$ at $\left.25^{\circ} \mathrm{C}\right), 2 \mathrm{mM} \mathrm{MgSO}_{4}, 1 \mu \mathrm{L}$ BSA, $200 \mu \mathrm{M}$ each dATP, dGTP, dCTP and dTTP, $1 \mu \mathrm{M}$ of each primer, one unit (U) of Taq polymerase (Run DNA Polymerase A\&A Biotechnology) and 10-20 ng of the DNA template. The PCR reactions for the rpoB genes were performed under the following conditions: (1) initial denaturation $4 \mathrm{~min}$ at $94^{\circ} \mathrm{C}$; (2) denaturation $35 \mathrm{~s}$ at $94^{\circ} \mathrm{C}$; (3) annealing $1 \mathrm{~min}$ at $48^{\circ} \mathrm{C}$; (4) elongation $1 \mathrm{~min}$ at $72^{\circ} \mathrm{C}$; (5) final elongation $7 \mathrm{~min}$ at $72^{\circ} \mathrm{C}$. Stages 2-4 were repeated 35 times. Finally, the products of amplification were visualized on 2\% agarose gel with GelView (Invitrogen ${ }^{\mathrm{TM}}$, Carlsbad, CA, USA) staining. The cleaned, pure PCR products were sequenced in both directions using an ABI BigDye 3.1 Terminator Cycle Kit (Applied Biosystems ${ }^{\circledR}$, Foster City, CA, USA) and the same primers were used for sequencing. For the procedures of amplification and sequencing of the rpo $\mathrm{C} 1$ genes, the primers from the website of the Royal Botanical Garden in Kew were used. Primers for the $r p o \mathrm{~A}, r p o \mathrm{~B}$ and $r p o \mathrm{C} 2$ genes were designed using the chloroplast genome of Chamaedaphne calyculata (Szczecińska et al. 2014), annotated as KJ463365.1 in the GenBank database (Benson et al. 2005). All sequences of the used primers are presented in Table 2.

The program Sequencher 4.1.4 (Gene Codes Corporation, Ann Arbor, MI, USA) was used for editing and assembling electropherograms. The program BioEdit 7 was used for manual adjustment and the program MUSCLE - for sequence alignment of the assembled sequences (Hall 1999; Edgar 2004). The conducted analyses enabled to remove the regions of ambiguous alignment and deficient or incomplete data (i.e., at the end and the beginning of these sequences). The obtained seqences of the rpo genes $(r p o \mathrm{~A}, r p o \mathrm{~B}, r p o \mathrm{C} 1$ and $r p o \mathrm{C} 2$ ) are deposited in the public repository-GenBank database - as KY523675-KY523838.

\subsection{Distribution of substitutions and phylogenetic informativeness (PI)}

The HyPhy program was used to estimate the distribution of substitution rates across the sites by applying a rate class to each site based on a general model characterized by reversibility (Pond \& Muse 2005). The DAMBE software was used to evaluate the level of nucleotide substitution saturations by plotting transitions and transversions against pairwise genetic distance (Xia et al. 2001; Xia 2013). The phylogenetic informativeness (PI) of rpo genes was estimated in the PhyDesign server and the phylogenetic informativeness profiles were plotted with reference to an uncalibrated tree (Lopez-Giraldez et al. 2011). The PATHd8 was used for an ultrametrisized tree used to overlay the historic changes in substitution rates, which were obtained with ML (Britton et al. 2007). The root of the tree was set at an evolutionary time of 1 and tips at the time of 0 for obtaining the relative ages for the clades. PI calculations of nucleotide data sets were also estimated using the HyPhy program, employing empirical base frequencies and a time-reversible model of substitution (Pond et al. 2005). The Rate4Site program was used for the amino acid (AA) data sets. In this program, the JTT model of evolution and ML inference method were used (Mayrose et al. 2004). Informativeness was calculated to exclude the influence of gene length on the outcome per site.

\subsection{Phylogenetic relationships}

Phylogenetic relationships were inferred by applying three methods: Bayesian inference (BI), maximum likelihood (ML) and maximum parsimony (MP). The MrBayes v. 3.2.2 program was used for Bayesian inference phylogenetic analyses with the priors set according to the output of jModelTest 2.1.7 (Hulsenbeck \& Ronquist 2001; Posada 2008; Darriba et al. 2012). The Bayesian Information Criterion (BIC) results were used as the basis to select optimal models of nucleotide

Table 2. The forward and reverse primer's sequences of DNA applied in the testing procedures

\begin{tabular}{lll}
\hline Region & Forward primer's sequence (5'-3') & Reverse primer's sequence (5'-3') \\
\hline rpoA & ATGAGTCGAGAAAACGGAAG & TTGTCGATTCATTTCATTGG \\
rpo B & AAGTGCATTGTTGGAACTGG & CCGTATGTGAAAAGAAGTATA \\
rpoC1 1 & TATGAAACCAGAATGGATGG & GAAAACATAAGTARRCGWGC \\
rpo 22 & AAAGAGATACGGCTTTGTACT & GGAATGCCAATCTTTCCTAAT \\
\hline
\end{tabular}


substitution for rpo sequences. The data partitioned for analyses and models for each gene were the same. The likelihood model parameters applied for the region were suitable for a general time-reversible model with a gamma-shaped distribution of rates across sites (TRN2). The estimation of the Bayesian inference was performed by running six incrementally-heated chains (MCMC algorithm) for 1,500,000 generations, sampling one out of every 100 generations of random trees. A test run was done to determine the number of generations that should be eliminated from consensus tree calculations. In the study, the first 30,000 generations were rejected as "burn-in". The Bayesian consensus tree was constructed using the remaining generations. FigTree v1.4.2 software was used to graphically adjust the generated phylogenetic trees.

MEGA v.6.06 software was used for conducting the ML and MP analyses (Tamura et al. 2013). Advanced software RAxML was used to produce the ML tree. The $\mathrm{T} 92+\mathrm{G}$ model of nucleotide substitution was used as a basis for ML analyses. The tree inference was performed with the Close Neighbor Interchange (CNI in maximum parsimony) in the MP method, the algorithm at the search level of 3 and the number of initial trees equal to 10 . The phylogeny was investigated both for the maximum likelihood and maximum parsimony using the bootstrap method with the number of bootstrap replications at the level of 1000 (Felsenstein 1985; Christelová et al. 2011).

\subsection{Positive selection pressure}

TreeSAAP v.3.2 software was used to study the occurrence of positive selection pressure at the protein level (Woolley et al. 2003). This program calculated the selective impact on structural and biochemical amino acid properties (31 properties) across a phylogenetic tree. For the classification of each property change, the gradient of eight categories was used, with lower categories denoting more conservative changes and higher categories indicating more radical changes. Next, a Z-test was performed to determine selection on the detected amino-acid properties, when the frequency of radical changes of 6,7 or 8 category, overstep the frequency prospective by chance, as indicated by positive z-scores. In the TreeSAAP software, each of the analyzed rpo genes was inspected using both the whole data set and a sliding window analysis (the width of reading frame equal to 15 codons). The results obtained in the TreeSAAP software allowed to detect positive destabilizing effect for each property contained in the particular amino acid residues.

\section{Results}

\subsection{Gene sequences}

Rpo gene fragments ranging from $633 \mathrm{bp}(r p o \mathrm{C} 2)$ to $743 \mathrm{bp}(\mathrm{rpoA})$ in length were used in this study (Table 3 ). The variability of rpo genes was caused entirely by substitutions, no indels were identified. The analyzed sequences belonged to 41 different species.

A slightly higher content of purines than pyrimidines and a more numerous amount of AT than GC bonds were present in the $r p o \mathrm{~A}, r p o \mathrm{~B}$ and $r p o \mathrm{C} 1$. A slightly higher content of pyrimidines over purines and a more numerous amount of AT than GC bonds were observed in the rpoC2 gene. In the group of tested genes, the highest level of variation and informative sites was noted in the $r p o \mathrm{C} 2$ gene $(13.9 \%, 5.68 \%)$. The rpoA gene has a substitution rate of 0.50 and it was characterized by slightly lower variability; the contribution of variable sites $(V)$ reached $9.69 \%$ and the parsimony-informative sites $(P i)$ reached $3.49 \%$. The lowest average rate of its evolution was noted in the rpoCl gene and it was 0.12 substitutions per nucleotide. The rpoC1 had the lowest level of variable sites $(6 \%)$ and the lowest number of parsimony-informative sites (1.71\%) (Table 3).

In this study, the slighter average rate of mutation in the rpo $\mathrm{B}$ and $r p o \mathrm{C} 1$ genes in the Erica genus corresponded to a higher variability of this rate within

Table 3. Comparison of the analyzed rpo gene fragments

\begin{tabular}{lcccc}
\hline & rpoA & rpoB & rpoC1 & rpoC2 \\
\hline Alignment length & 743 & 654 & 699 & 633 \\
Sequence length & $742-743$ & 654 & 699 & 633 \\
Site rates & 0.508 & 0.348 & 0.125 & 0.518 \\
Variable characters $(V)$ & $72(9.69 \%)$ & $56(8.56 \%)$ & $42(6 \%)$ & $88(13.9 \%)$ \\
Parsimony - informative sites $(P i)$ & $26(3.49 \%)$ & $18(2.75 \%)$ & $12(1.71 \%)$ & $36(5.68 \%)$ \\
Purines (\%) & 53.761 & 54.451 & 51.876 & 48.04 \\
Pyrimidines (\%) & 46.239 & 45.549 & 48.124 & 51.96 \\
GC (\%) & 32.95 & 39.254 & 41.345 & 32.262 \\
Transition/Transversion bias $(R)$ & 0.57 & 1.09 & 0.68 & 0.8 \\
Number of the synonymous substitutions & 18 & 28 & 9 & 34 \\
Number of the non-synonymous substitutions & 85 & 59 & 35 & 69 \\
\hline
\end{tabular}




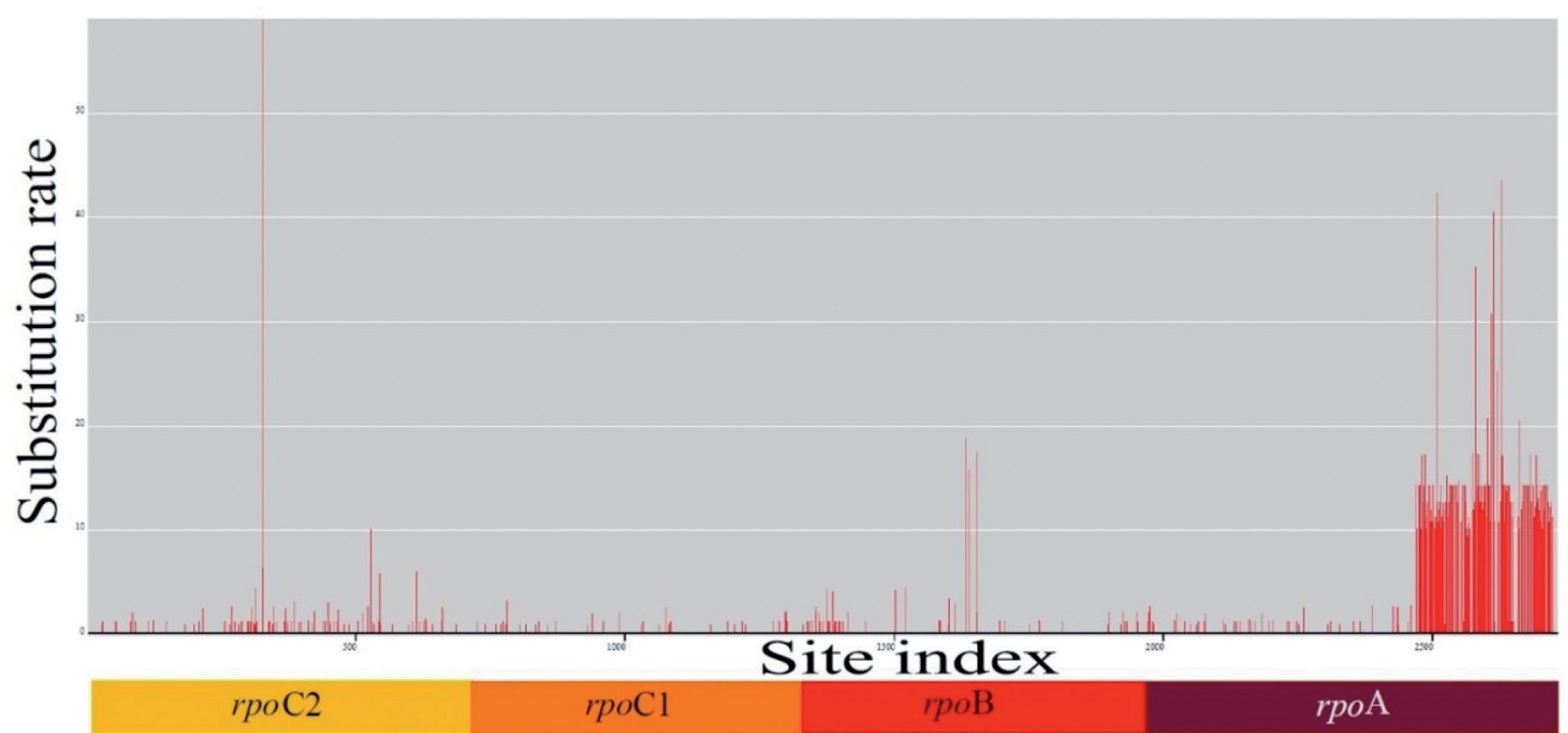

Fig. 1. Result of the distribution of substitution analyzes shown in HyPhy software computed with the TRN model of evolution. A colored slice below the plot represent the proportional position of sites in the analyzed chloroplast gene fragments (yellow - rpoC2, orange - rpoC1, red $-r p o B$, purple $-r p o A$ )

these genes. The rpo $\mathrm{B}$ and $r p o \mathrm{C} 1$ genes contain large conserved regions and a few extremely variable sites. A high density of variable sites occurs in the region of the rpoA gene (Fig. 1). Site rate variation has an important impact on phylogenetic analysis, especially sequence evolution. A strong variability indicator in rpoA shows that some of the substitutions occurred at fast-changing sites.

\subsection{Phylogenetic informativeness and the phylogenetic tree}

Stating the number of transitions and transversions with the genetic distance for each pair of sequences allowed the state of substitution saturation in examined rpo genes to be calculated (Fig. 2). The results received for the rpo genes show that the number of substitutions
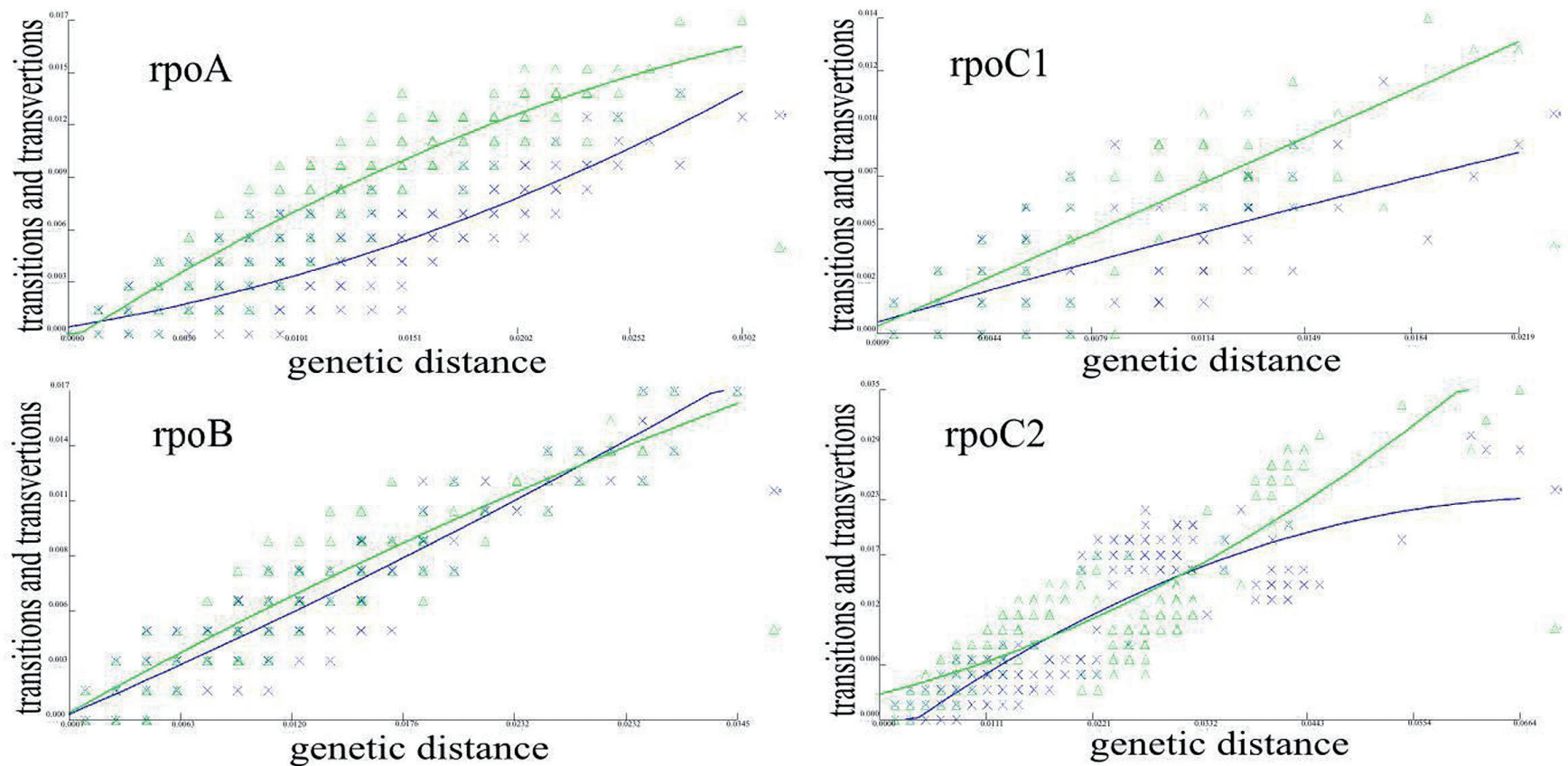

Fig. 2. Transitions and transversions vs divergence plots (Xs - transitions, $\Delta v$ - transversions; lines show the main trend). The estimated number of transitions and transversions for each pairwise comparison was plotted against the genetic distance 

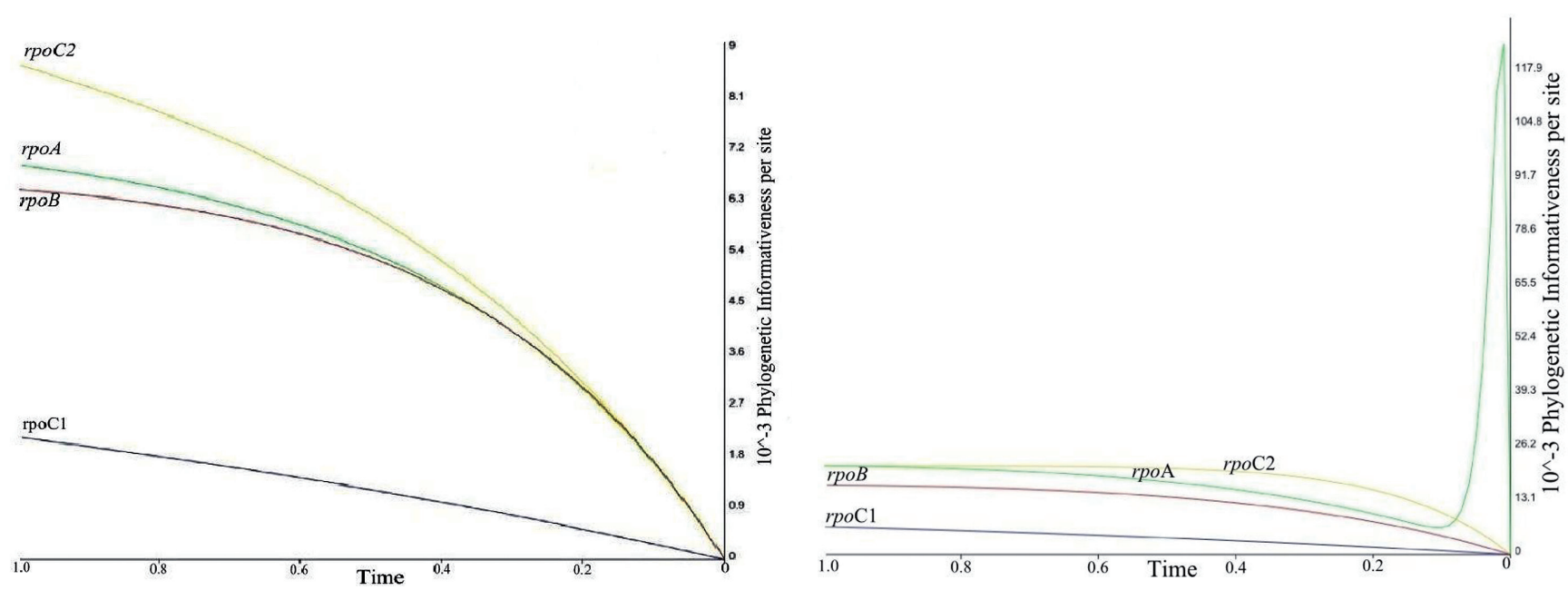

Fig. 3. The charts obtained by analysis using PhyDesign software correspond to phylogenetic informativeness per site for the studied rpo genes measured from the nucleotide (A) and amino acid sequences (B) - the ultrametrisized ML tree derived from the dataset of all tested rpo genes was used for the calibration of the time axis

progressed with the increase in genetic distance. A lower increasing tendency was only noted in the number of transitions in the rpoC2 gene. For the rpoA and rpoC1 genes, a distinct advantage of transversions over transitions was noted.

The study also shows that the difference in the load of information carried by two types of data depends on the comparison of the PI profile based on nucleotide sequences with the profile obtained for the amino acid sequences. The PI analysis revealed that among the tested rpo genes, the rpoC2 gene shows a higher usefulness as a phylogenetic marker for the genus Erica. In the rpoC2 gene, the high informativeness of the nucleotide sequence (Fig. 3A) was correlated with a strong phy-

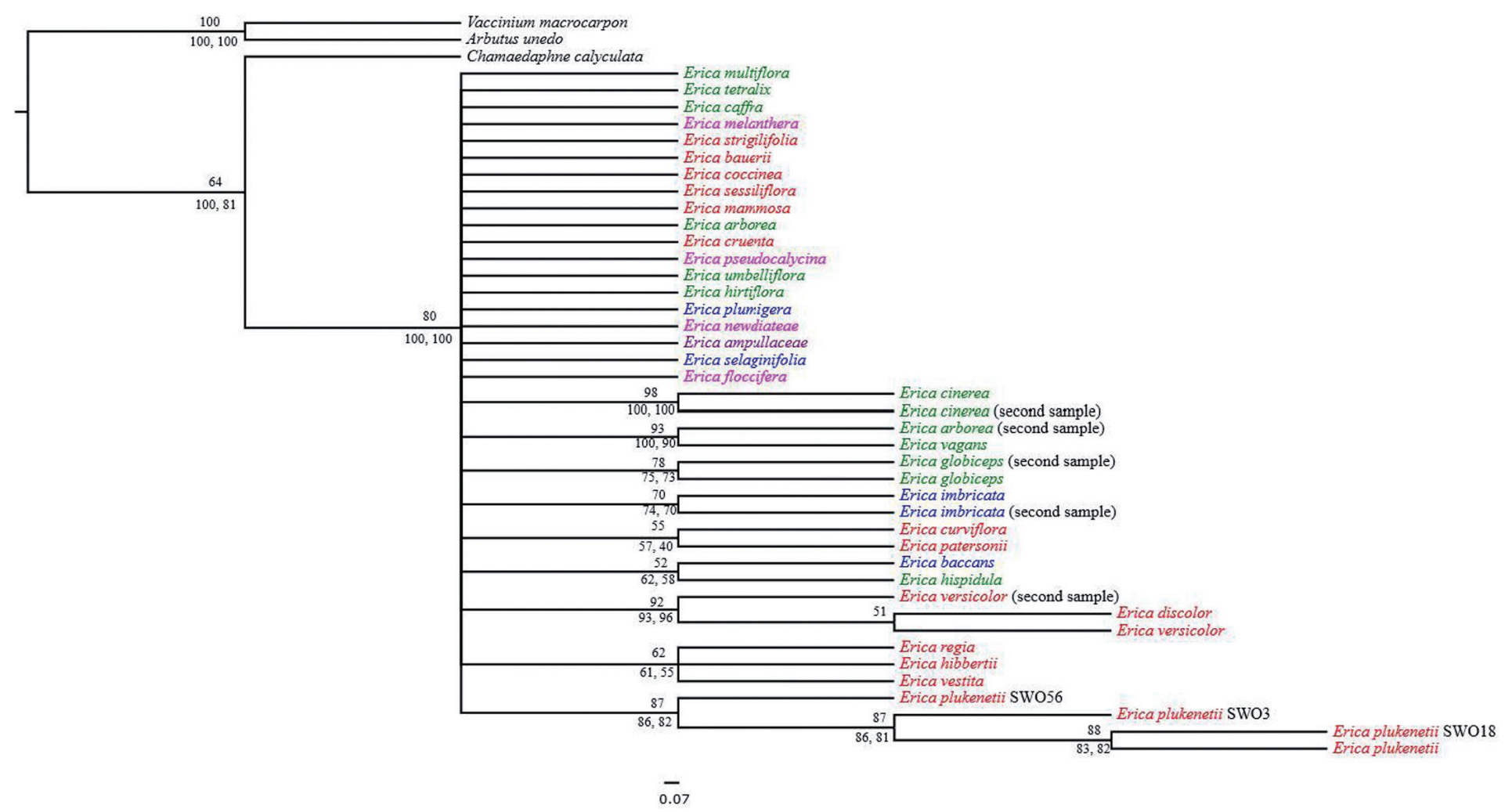

Fig. 4. A consensus phylogenetic tree obtained by Bayesian analysis of the rpo genes. Colors of the species names denote subgeneric affiliation: red - Syringodea, purple - Stellanthe, green - Euerica, blue - Chlamydanthe, fuchsia - Platystoma. Names in black denote the outgroup. Bootstrap values lower than $50 \%$ are hidden. Numbers under the branches represent bootstrap support obtained by maximum likelihood and maximum parsimony methods. The MP value is placed before the comma and ML value - after the comma 
logenetic signal at the amino acid level (Fig. 3B). This shows a high convergence of protein sequence evolution with the phylogenetic tree topology. The level of informativeness at the nucleotide and amino acid levels was similar.

The phylogenetic tree received with the MP method determined a consensus of the 2,727 most parsimonious trees with a length of 382 steps each $(\mathrm{CI}=0.743455$ and $\mathrm{RI}=0.617188)$. The topology of the phylogenetic tree is completely compatible with the Bayesian inference results. The ML tree obtained from analyses of concatenated nucleotide sequences of rpo genes has similar topology to the MP and Bayesian trees. The compiled results of the phylogenetic analyses are presented in Fig.4. Phylogenetic analysis based on the rpo gene sequence variation does not show the whole picture of the genus Erica systematics. Although it shows valuable information about the phylogenetic relationships between the examined Erica species, there are several exemptions from the taxonomic division introduced by Oliver (Oliver 1993; Oliver et al. 2003).

\subsection{Positive Selective Pressure}

The examined genes showed differences in the content of silent mutations and non-synonymous mutations. For the rpo genes, the predominance of variable sites containing non-synonymous substitutions (Table 3) were noted. All genes had fewer synonymous sites. The highest number and highest percentage of non-synonymous sites in relation to all variable sites was found in the rpoC2 and rpoA genes, where the number of variable sites was equal. The rpoC2 had 69 non-synonymous substitutions, while rpoA had 85 non-synonymous substitutions.

Some of the observed non-synonymous mutations resulted in important changes in physicochemical properties of amino acids.

\section{Discussion}

There are insufficient data in the available literature to compare the variation of rpo genes in Erica species with the variation in other genera of vascular plants. Thus, our results based on the analyses of rpo gene fragments, can be related to studies of the rpo gene variability in Lamium species. The data published by Krawczyk and Sawicki (2013), indicate that the level of variable sites observed in the analyzed genes in the genus Erica was higher than in the genus Lamium. The variability of $r p o \mathrm{~A}, r p o \mathrm{~B}, r p o \mathrm{C} 1$ and $r p o \mathrm{C} 2$ genes observed in the genus Erica (Table 3) was visibly higher than in the genus Lamium, where the degree of variability of these genes amounted to $V=5.91 \%, V=2.52 \%$, $V=2.85 \%$ and $V=5.03 \%$, respectively. Similarly, the comparison of results of the rpo gene variability ob- served in the tribe Triticeae and family Myristicaceae and in the genus Erica showed that variability in the two former taxa is lower than in the genus analyzed in this work, although, it was parallel to other phylogenetic markers, which indicates that it is still comparatively high (Petersen \& Seberg 1997; Newmaster et al. 2008).

The inherence of highly variable sites increases the likelihood of reverse mutation or homoplasy, which hinders a faultless phylogenetic relationship reconstruction (Little \& Hallick 1988). Our study supports the results of research conducted at higher taxonomic levels, as in the division Magnoliophyta. In this division, the rpoA and $r p o \mathrm{C} 2$ genes proved to be better phylogenetic markers than the rpo $\mathrm{B}$ and $r p o \mathrm{C} 1$ genes (Logacheva et al. 2007). Similar conclusions can be drawn from the studies of the genus Lamium (Krawczyk \& Sawicki 2013). The diversity profile of $r p o \mathrm{~A}$ and $r p o \mathrm{C} 2$ genes makes their phylogenetic signal more precise. With respect to molecular taxonomy, a steady rate of substitution is tendered in a given genome section (Yang 1996; Lió \& Goldman 1998).

Among all four graphs, illustrating the state of substitution saturation in the examined rpo genes, none took the form of a plateau, which is typical of the state of saturation with substitutions. If the separate fragments of genome have not yet reached the level of substitution saturation, they can provide a reliable phylogenetic signal. However, determining whether the similarity in the pair of sequences is a homoplasious trait or a homologous trait derived from a common ancestor is more difficult (Jeffroy et al. 2006; Townsend 2007). The signal is not sufficient to resolve the phylogeny at the genus level in the genus Erica. The obtained results suggest that the rpo genes not seem to be useful in phylogenetic inference in the genus Erica. Finding a suitable molecular marker to resolve relationships within a genus will be very useful for ecological and evolutionary research in the genus Erica.

The phylogenetic informativeness analysis of individual rpo genes allows a congruous inference to be drawn. The obtained profiles of PI indicated that the tested genes reached the apex of informativeness for the events evolutionarily older than the speciation within the genus Erica. This indicates that the information noise that arose from the accumulation of mutations carrying non-phylogenetic signal was diminished (Townsend et al. 2008; Townsend \& Leuenberger 2011).

The PI analysis of the PI profile based on nucleotide sequences with the profile based on the amino acid sequences, revealed that among the tested rpo genes, the rpo $\mathrm{C} 2$ gene shows a higher usefulness as a phylogenetic marker for the genus Erica. The level of informativeness at the nucleotide and amino acid levels was suchlike. The interpretation of both graphs shown in Fig. 3 has to be cautious, because the PI values are presented per 
site. If we want to confront the PI values for nucleotide and amino acid types of data, the scores demonstrated on the Y-axis of the graph in Fig. 3B should be divided by three, because the amino acid sequences are three times shorter than the nucleotide sequences. The results obtained based on this principle prove that the phylogenetic signal carried by examined rpo genes was quite similar at the amino acid and nucleotide levels. The spike in phylogenetic informativeness in the rpoA gene, inferred from amino acid sequences for recent divergences, might coincide with the high density of variable sites occurring in the region of the rpoA gene received in HyPhy. This spike probably results from the maximum likelihood estimate for the rate of several sites and has its peak at infinity. The result of this type of analysis was highly reliable, even though the amount of information was lower than in the case of nucleotides - as in the case of the genus Lamium analysis. In these studies, the most useful phylogenetic marker proved to be rpoA, in which high informativeness at the nucleotide level corresponds to a strong signal at the amino acid level. In other genes, there was a discrepancy recorded between informativeness at the nucleotide and amino acid levels (Krawczyk \& Sawicki 2013). This may be explained by the fact that the analysis based on the amino acid sequence was less obscured by the information noise compared to the analysis involving nucleotide sequences (Townsend et al. 2008).

The phylogenetic tree of the genus Erica, calculated based on the rpo genes, was generally in agreement with the results based on an analysis of six, mainly non-coding, chloroplast markers and is helpful in determining the phylogenetic relationships within the studied taxon. These results are similar to those obtained in the study of the rpo genes in Lamium (Krawczyk \& Sawicki 2013). This work illustrates the considerable genetic distance between the representatives of the outgroup: Vaccinium macrocarpon, Arbutus unedo and Chamaedapne calyculata. This is indicative of the early separation of this phylogenetic line. The topology of this phylogenetic tree indicates a closer relationship between Chamaedaphne calyculata and the Erica species examined, than between Erica and two others species from the outgroup. The representatives of all subgenera of the genus Erica are not grouped in one ordination and they do not form the clades that validate the division of the genus Erica into subgenera and sections. The subgenera Euerica and Chlamydanthe were interesting because of the relationships between individual species. E. baccans (subgenus Chlamydanthe) is phylogenetically closer to E. hispidula (subgenus Euerica) than to other species from the subgenus Chlamydanthe. The subgenus Syrignodea is also interesting because of relationships between individual sections. The noted changes in the rрoA, rроB and rpoC2 genes in the Syringodea subgenus were also noticeable at the protein level (Appendix 1). The analysis of the phylogenetic tree may indicate that the ancestor of Erica genus was bicontinental Erica multiflora from the subgenus Euerica. Two individuals of the same species, belonging to the subgenus Euerica are of interest because of the problem associated with $E$. arborea. The second specimen of $E$. arborea is phylogenetically closer to $E$. vagans than to E. arborea. The result obtained with the ML method also showed similar separation between the first and second specimen of E. arborea. A similar phenomenon was observed in the subgenus Syringodea, i.e., E. versicolor was phylogenetically a little closer to $E$. discolor than to the second specimen of $E$. versicolor. The difference occurs in the case of E. versicolor, which has a greater similarity to the second sample of E. versicolor than to E. discolor. This probably results from the wrong identification of $E$. arborea or, alternatively, we are witnessing the separation of a new species. This relationship was also noted at the nucleotide level and was confirmed by the presence of an adaptive mutation in the protein encoded by the $r p o \mathrm{~B}$ gene, where many changes in the properties of the amino acid were detected in E. arborea and $E$. vagans. The phylogenetic tree reveals a long distance between the representatives of one species (as for $E$. arborea).

An analysis of the changes in amino acid properties indicated that, with a few exceptions, these changes were not reflected in the construction of the phylogenetic tree. Minor exceptions were common changes in the rpoC2 gene in E. baccans and E. hispidula, E. cinerea and the second sample of E. cinerea, and E. multiflora and $E$. tetralix. The changes in the rpoC1 gene occurred in E. versicolor, the second sample of E. versicolor and E. discolor, and in E. imbricata and the second sample of $E$. imbricata. The common changes in the rpoA gene were observed in $E$. cinerea and the second sample of $E$. cinerea, and also E. multiflora and E. tetralix. Examples of these common changes in the rpoB gene were not found (Appendix 1).

The strong conclusion one can make based on the presented tree is that the genus Erica is monophyletic. There are no clades grouping together taxa belonging to different subgenera and almost no well-supported clades at all. Some species fall into one clade, but some not (for example E. arborea).

Two specimens of $E$. arborea are not grouped together and one of them is sister to another species. Based on the presented tree, it is difficult to conclude about genetic relationships. Both studied samples originated from Spain, but not from the same location - the first sample was collected in Montradue and the second in Cap de Creus. This difference in origin might explain the separate grouping of E. arborea specimens in the phylogenetic tree. A similar situation was observed 
for some species of the genus Lamium. The phylogenetic analysis showed that $L$. album 218 was closer to L. tomentosum than L. album 220 and L. album 222 (Krawczyk \& Sawicki 2013).

The phylogenetic tree and juxtaposition of amino acid property changes did not allow the various representatives of Erica to be organized or sorted into clades. Radical amino acid property changes under the positive destabilizing selection were observed in all rpo genes. Specific changes in the properties of amino acids encoded by these genes often occurred in a number of codons simultaneously. Most amino acid property changes were observed in the rpoB gene ( 7 from " 8 " category of change, 5 from " 7 " and 7 from " 6 "), while the fewest property changes were noted in the rpoC1 gene ( 2 from " 8 " category of changes, 5 from " 7 " and 2 from "6"). Numerous property changes from the category " 8 " occurred in the rpoA gene ( 9 properties). In relation to the rpo $\mathrm{C} 2$ gene, most amino acid properties changes occurred in the subgenera Chlamydanthe, Euerica and Syringodea. There were no changes in the subgenus Stellanthe and only one in the subgenus Platystoma. For the rpoC1 gene, the most numerous changes occurred in the subgenus Syringodea. There were no changes in the subgenus Stellanthe and only a few changes recorded in other subgenera. For the rpo $\mathrm{B}$ gene, numerous amino acid property changes were noted in the subgenera Syringodea and Euerica, while no changes were observed in the subgenus Stellanthe and only a few changes in other subgenera. For the rpoA gene, numerous changes were noted in the subgenera Syringodea, Euerica and Chlamydanthe. For the sub- genera Stellanthe and Platystoma, only a few individual amino acid properties changes were observed. Some changes in amino acids were specific to subgenera, but those are not sufficient to classify species to subgenera. As far as we know, the discussed Erica genus has never been addressed in molecular studies.

The results obtained for Erica show that the phylogeny based on more than 2,000 nucleotide long alignment is poorly resolved (the tree contains large polytomies and multiple clades with low support). The phylogenetic signal has not been obscured by multiple substitutions (no saturation), but there is clearly no evidence that variability of PEP sequences enables estimation of a robust phylogeny of Erica. The results of this study show that the rpo genes are not useful phylogenetic markers that can be helpful in the reconstruction of evolution of the genus Erica. Coding regions contained a high, but not reliable phylogenetic signal. The value of this signal may be increased by an analysis of the changes in the amino acid chain. Of the all examined rpo genes, the most useful phylogenetic marker was the gene rpoC2, while the least suitable gene turned out to be rpoC1. In four tested genes, the destabilizing effects of positive pressure were noted. This illustrated the relations between mutations fixed by positive selection and the separation of phylogenetic lines within the genus tested. A notable advantage is the ease of alignment of the analyzed sequences.

Acknowledgements. This work was made possible thanks to financial support from the Polish State Committee for Scientific Research (KBN grant N303 807840).

\section{References}

Allison L. A., Simon L. D. \& Maliga P. 1996. Deletion of rpoB reveals a second distinct transcription system in plastids of higher plants. EMBO Journal 15: 28022809.

Benson D. A., Karsch-Mizrachi I., Lipman D. J., Ostell J. \& WheELER D. L. 2005. GenBank. Nucleic Acids Research. 40: 34-38.

Bentham G. 1839. Ericaceae. In A. P. De Candolle, Prodromus systematis naturalis regni vegetabilis, 7: 580-733. Treutel \& Weiss, Paris.

Blazier J. C., Ruhlman T. A., Weng M. L., Rehman S. K., SABIR J. S. M. \& JANSEN R. K. 2016. Divergence of RNA polymerase $\alpha$ subunits in angiosperm plastid genomes is mediated by genomic rearrangement. Scientific Reports. DOI: 10.1038/srep24595

Botanical Garden in Kew website. Available online: http:// www.kew.org/barcoding/protocols/ (accessed on 21 January 2017).

Britton T., Anderson C. L., Jacquet D., Lundqvist S. \& BREMER K. 2007. Estimating divergence times in large phylogenetic trees. Systematic Biology. 56: 741-752.
Bruzone M. C., Fontenla S. B. \& Vohník M. 2015. Is the prominent ericoid mycorrhizal fungus Rhizoscyphus ericae absent in the Southern Hemisphere's Ericaceae? A case study on the diversity of root mycobionts in Gaultheria spp. From northwest Patagonia, Argentina. Mycorrhiza 25(1): 25-40. DOI 10.1007/s00572-014-0586-3

Chelo I. M., ZÉ-ZÉ L. \& Tenreiro R. 2007. Congruence of evolutionary relationships inside the LeuconostocOenococcus-Weissella clade assessed by phylogenetic analysis of the $16 \mathrm{~S}$ rRNA gene, dnaA, gyrB, rpoC and dnaK. International Journal of Systematic and Evolutionary Microbiology 57: 276-286.

Chotewutmontri P. \& Barkan A. 2016. Dynamics of Chloroplast Translation during Chloroplast Differentiation in Maize. PLoS Genet 12 (7): e1006106. doi:10.1371/ journal.pgen.1006106

Christelová P., Valárik M., Hřibová E., de Langhe E. \& DoležEl J. 2011. A multi-gene sequence-based phylogeny of the Musaceae (banana) family. BMC Evolutionary Biology. 11:103. doi: 10.1186/14712148-11-103 
Darriba D., Taboada G. L., Doallo R. \& Posada D. 2012. jModelTest 2: more models, new heuristics and parallel computing. Nature Methods 9(8): 772.

EdGAR R. C. 2004. MUSCLE: multiple sequence alignment with high accuracy and high throughput. Nucleic Acids Research 32(5): 1792-97.

Felsenstein J. 1985. Confidence limits on phylogenies: An approach using the bootstrap. Evolution 39: 783-791.

Fig Tree, version 1.4.2. Software for molecular evolution, phylogenetics and epidemiology. Available online: http://tree.bio.ed.ac.uk/software/figtree/ (accessed on 29 January 2017).

GillesPiE E. \& KRON K. 2010. Molecular phylogenic relationships and a revised classification of the subfamily Ericoidae (Ericaceae). Molecular Phylogenetics and Evolution 56: 343-354.

GLen H. F. 2002. Cultivated Plants of Southern Africa. 428 pp. Jacana, Johannesburg.

Hall T. A. 1999. BioEdit: A user-friendly biological sequence alignment editor and analysis program for Windows 95/98/NT. Nuclear Acids Symposium Series 41: 95-98.

Hansen I. 1950. Die europäischen Arten der Gattung Erica L. Bot. Jarhb. 75: 1-81.

HulsenBeck J. P. \& RonQuist F. 2001. MRBAYES: Bayesian inference of phylogenetic trees. Bioinformatics 17 : 754-755.

Jefrroy O., Brinkmann H., Delsuc F. \& Philippe H. 2006. Phylogenomics: The beginning of incongruence? Trends in Genetics 22: 225-231.

Korczak B., Christensen H., Emler S., Frey J. \& Kuhnert P. 2004. Phylogeny of the family Pasteurellaceae based on rpoB sequences. International Journal of Systematic and Evolutionary Microbiology 54: 1393-1399.

Krause K., Falk J., Humbeck K. \& Krupinska K. 1998. Responses of the transcriptional apparatus of barley chloroplasts to a prolonged dark period and to subsequent re-illumination. Journal of Plant Physiology 104: 143-152.

Krawczyk K. \& SAwicki J. 2013. The Uneven Rate of the Molecular Evolution of Gene Sequences of DNADependent RNA Polymerase I of the Genus Lamium L. International Journal of Molecular Science 14: 11376-11391.

Liere K., Weine A. \& Borner T. 2011. The transcription machineries of plant mitochondria and chloroplasts: composition, function and regulation. Journal of Plant Physiology 168: 1345-1360.

Linder H. P. 2003. The radiation of the Cape flora, southern Africa. Biological Review. 78: 597-638.

Lió P. \& Goldman N. 1998. Models of molecular evolution and phylogeny. Genome Research 8: 1233-1244.

Little M. C. \& Hallick R. B. 1988. Chloroplast rpoA, rpoB, and rpoC genes specify at least three components of a chloroplast DNA-dependent RNA polymerase active in tRNA and mRNA transcription. Journal of Biological Chemistry 263: 14302-14307.

Logacheva M. D., Penin A. A., SAmigullin T. H., VallejoRoman C. M. \& Antonov A. S. 2007. Phylogeny of flowering plants by the chloroplast genome sequences:
In search of a "Lucky Gene". Biochemistry 72: 13241330.

Lopez-Giraldez F. \& Townsend J. P. 2011. PhyDesign: an online application for profiling phylogenetic informativeness. BMC Evolutionary Biology. doi:10.1186/ 1471-2148-11-152.

Maddison W. P. \& KNOWLES L. L. 2006. Inferring phylogeny despite incomplete lineage sorting. Systematical Biology 55: 21-30.

Mayrose I., Graur D., Ben-Tal N. \& Pupko T. 2004. Comparison of site-specific rate-inference methods for protein sequences: Empirical Bayesian methods are superior. Molecular Biology and Evolution 21: 1781-1791

McGuire A. F. \& Kron K. A. 2005. Phylogenetic relationships of European and African Ericas. International Journal of Plant Science 166: 311-318.

Nei M. \& Kumar S. 2000. Molecular Evolution and Phylogenetics. xiv+333 pp. Oxford University Press, New York, NY, USA.

Newmaster S. G, Fazekas A. J, Steeves R. A. D. \& Janovec J. 2008. Testing candidate plant barcode regions in the Myristicaceae. Molecular Ecology Research 8: 480-490.

Ojeda F., Budde K. B. \& Heuertz M. 2015. Biogeography and evolution of seeder and resprouter forms of Erica coccinea (Ericaceae) in the fire-prone Cape fynbos. Plant Ecology. DOI: 10.1007/s11258-015-0539-8.

Oliver E. G. H. 1993. Studies in the Ericoideae (Ericaceae). XI. The generic relationship between Erica and Blaeria. Kew Bulletin 48: 771-780.

Oliver E. G. H. 2000. Systematics of Ericeae (Ericaceae: Ericoideae): species with indehiscent and partially dehiscent fruits. Contributions from the Bolus Herbarium 19: 1-483.

Oliver E. G. H. 1993. Studies in the Ericoideae (Ericaceae). XII. The placing of the genus Blaeria into synonymy under Erica; nomenclatural and taxonomic changes for the southern African region. Bothalia 23: 1-7.

Oliver E. G. H. \& Oliver I. M. 2003. Ericaceae. In: G. GerMishuizen \& N. L. Meyer (eds.). Plants of southern Africa: an annotated checklist, pp 424-451. Strelitzia. National Botanical Institute, Pretoria.

Petersen G. \& Seberg O. 1997. Phylogenetic analysis of the Triticeae (Poaceae) based on rpoA sequence data. Molecular Phylogenetics and Evolution 7: 217-230.

Pirie M. D., Oliver E. G. H. \& Bellstedt D. U. 2011. A densely sampled ITS phylogeny of the Cape flagship genus Erica L. suggest numerous shifts in floral macro-morphology. Molecular Phylogenetics and Evolution 61: 593-601.

Posada D. 2008. jModelTest: Phylogenetic Model Averaging. Molecular Biology and Evolution 25: 1253 1256.

Pond S. L. K. \& Muse S. V. 2005. HyPhy: Hypothesis testing using phylogenies. Bioinformatics 21: 676-679.

Schumann D., Kirsten G. \& Oliver E. G. H. 1992. Ericas of South Africa. 272 pp. Fernwood Press, Cape Town.

Serino G. \& Maliga P. 1998. RNA polymerase subunits encoded by the plastid rpo genes are not shared with 
the nucleus-encoded plastid enzyme. Plant Physiology 117: 1165-1170.

Stevens P. F., Luteyn J., Oliver E. G. H., Bell T. L., Brown E. A., Crowden R. K., George A. S., Jordan G. J., Ladd P., Lemson K., McClean C. B., Menadue Y., Pate J. S., Stace H. M. \& Weiller C. M. 2004. Ericaceae. In: K. KubitzKi (ed.). The Families and Genera of Vascular Plants, pp. 145-194. Springer-Verlad, Berlin-Heidelberg New York.

Szczecińska M., Gomolińska A., Szkudlarz P. \& Sawicki J. 2014. Plastid and nuclear genomic resources of a relict and endangered plant species: Chamaedaphne calyculata (L.) Moench (Ericaceae). Turkish Journal of Botany 38: 1229-1238.

Tamura K., Stecher G., Peterson D., Filipski A. \& Kumar S. 2013. MEGA 6: Molecular Evolutionary Genetics Analysis Version 6.0. Molecular Biology and Evolution 30: 2725-2729.

TownsEnd J. P. 2007. Profiling phylogenetic informativeness. Systematic Biology 56: 222-231.

Townsend J. P., López-Giráldez F. \& Friedman R. 2008. The phylogenetic informativeness of nucleotide and amino acid sequences for reconstructing the vertebrate tree. Journal Molecular of Systematic and Evolution 67: 437-447.
Townsend J. P. \& Leuenberger C. 2011. Taxon sampling and the optimal rates of evolution for phylogenetic inference. Systematic Biology 60: 358-365.

Woolley S., Johnson J., Smith M. J., Crandall K. A. \& McClellan D. A. 2003. TreeSAAP: Selection on amino acid properties using phylogenetic trees. Bioinformatics 19: 671-672.

XIA X. \& XIE Z. 2001. DAMBE: Software package for data analysis in molecular biology and evolution. Journal of Heredity 92: 371-373.

XIA X. 2013. DAMBE 5: A Comprehensive Software Package for Data Analysis in Molecular Biology and Evolution. Molecular Biology and Evolution 30(7): 1720-1728.

YAGI Y. \& Shina T. 2014. Recent advances in the study of chloroplast gene expression and its evolution. Front Plant Science 5: 61-68.

YANG Z. 1996. Among site rate variation and its impact on phylogenetic analyses. Trends in Ecology and Evolution 11: 367-372.

Yoichi W. \& Tomaru N. 2014. Patterns of geographic distribution have a considerable influence on population genetic structure in one common and two rare species of Rhododendron (Ericaceae). Tree Genetics \& Genomes 10: 827-837. 
Appendix 1. Characteristics of radical amino acid properties changes under positive destabilizing selection in the rpo genes (an outgroup not included)

\begin{tabular}{|c|c|c|c|c|c|c|}
\hline Gene & Codon & Branch & $\begin{array}{l}\text { Amino acid } \\
\text { change }\end{array}$ & Property & $\begin{array}{l}\text { Category } \\
\text { of change }\end{array}$ & $\begin{array}{l}\text { Statistical } \\
\text { error }\end{array}$ \\
\hline \multirow[t]{51}{*}{ rpoC2 } & 112 & Erica hirtiflora & L into $\mathrm{E}$ & Chromatographic & 8 & 0.001 \\
\hline & 125 & E. baccans & $\mathrm{F}$ into $\mathrm{C}$ & index & & \\
\hline & 180 & E. bauerii, E. imbricata, $E$ & F into $\mathrm{C}$ & & & \\
\hline & & $\begin{array}{l}\text { imbricata } 2, E \text {. vestita, E. coccinea, } \\
\text { E. mammosa, E. sessiliflora, E. }\end{array}$ & & & & \\
\hline & & hibbertii, E. plukenetii SWO3, E. & & & & \\
\hline & & $\begin{array}{l}\text { plukenetii SWO18, E. plukenetii } \\
\text { SWO56, E. plukenetii2 }\end{array}$ & & & & \\
\hline & 125 & E. baccans & $\mathrm{F}$ into $\mathrm{C}$ & Composition & 8 & 0.050 \\
\hline & 180 & E. bauerii, E. imbricata, $E$. & $\mathrm{F}$ into $\mathrm{C}$ & (C) & & \\
\hline & & & & & & \\
\hline & & hibberii, E. plukenetii SWO3, E. & & & & \\
\hline & & plukenetii SWO18, E. plukenetii & & & & \\
\hline & & SWO56, E. plukenetii2 & & & & \\
\hline & 114 & E. baccans & W into $\mathrm{G}$ & $\begin{array}{l}\text { Molecular } \\
\text { volume }\end{array}$ & 8 & 0.050 \\
\hline & 114 & E. baccans & $\mathrm{W}$ into $\mathrm{G}$ & Molecular & 8 & 0.050 \\
\hline & 114 & E. baccans & $\mathrm{W}$ into $\mathrm{G}$ & $\begin{array}{l}\text { Partial specific } \\
\text { volume }\left(\mathrm{v}_{\mathrm{f}}\right)\end{array}$ & 8 & 0.050 \\
\hline & 114 & E. baccans & W into $\mathrm{G}$ & Refractive index & 8 & 0.050 \\
\hline & 107 & E. baccans, E. hirtiflora & $\mathrm{N}$ into I & Buriedness & 7 & 0.050 \\
\hline & 111 & E. selaginifolia & $\mathrm{Q}$ into $\mathrm{L}$ & & & \\
\hline & 112 & E. hirtiflora & L into $\mathrm{E}$ & & & \\
\hline & 123 & E. baccans, E. hispidula & $\mathrm{N}$ into I & & & \\
\hline & 148 & E. baccans & $\mathrm{N}$ into I & & & \\
\hline & 107 & E. baccans, E. hirtiflora & $\mathrm{N}$ into I & Coil tendencies & 7 & 0.050 \\
\hline & 114 & E. baccans & W into $G$ & & & \\
\hline & 123 & E. baccans, E. hispidula & $\mathrm{N}$ into I & & & \\
\hline & 148 & E. baccans & $\mathrm{N}$ into I & & & \\
\hline & 93 & E. cinerea, E. cinerea2 & $\mathrm{H}$ into $\mathrm{Y}$ & $\begin{array}{l}\text { Power to be at } \\
\text { the middle of } \\
\text { alpha-helix }\left(\mathrm{a}_{\mathrm{m}}\right)\end{array}$ & 7 & 0.050 \\
\hline & 90 & E. hirtiflora & L into $\mathrm{S}$ & Coil tendencies & 6 & 0.050 \\
\hline & 16 & E. baccans & $\mathrm{T}$ into $\mathrm{K}$ & Isoelectric point & 6 & 0.050 \\
\hline & 59 & E. baccans & $\mathrm{P}$ into $\mathrm{R}$ & $\left(\mathrm{pH}_{\mathrm{i}}\right)$ & & \\
\hline & 102 & E. multiflora, E. tetralix & G into $\mathrm{R}$ & & & \\
\hline & 107 & $\begin{array}{l}\text { E. caffra, E. mammosa, } E \text {. } \\
\text { patersonii, E. selaginifolia, E. } \\
\text { sessiliflora, E. strigilifolia }\end{array}$ & $\mathrm{K}$ into $\mathrm{N}$ & & & \\
\hline & 107 & E. plumigera & $\mathrm{K}$ into $\mathrm{T}$ & & & \\
\hline & 114 & E. selaginifolia & W into $\mathrm{R}$ & & & \\
\hline & 121 & E. plumigera & $\mathrm{K}$ into $\mathrm{N}$ & & & \\
\hline & 127 & E. baccans & $\mathrm{T}$ into $\mathrm{K}$ & & & \\
\hline & 176 & E. pseudocalycina & $\mathrm{N}$ into $\mathrm{K}$ & & & \\
\hline & 179 & E. cinerea, E. cinerea 2 & $\mathrm{~K}$ into $\mathrm{N}$ & & & \\
\hline & 68 & E. multiflora & D into $G$ & Polar & 6 & 0.050 \\
\hline & 98 & E. cruenta & I into $\mathrm{K}$ & requirement & & \\
\hline & 107 & E. hirtiflora, E. baccans & $\mathrm{N}$ into I & & & \\
\hline & 121 & E. baccans, E. hispidula & $\mathrm{K}$ into I & & & \\
\hline & 123 & E. baccans, E. hispidula & $\mathrm{N}$ into I & & & \\
\hline & 148 & E. baccans & $\mathrm{N}$ into I & & & \\
\hline & 16 & E. baccans & $\mathrm{T}$ into $\mathrm{K}$ & Total non- & 6 & 0.050 \\
\hline & 68 & E. multiflora & D into $G$ & bonded energy & & \\
\hline & 102 & E. multiflora, E. tetralix & G into $\mathrm{R}$ & & & \\
\hline & 107 & E. baccans, E. hirtiflora & $\mathrm{N}$ into I & & & \\
\hline & 107 & E. plumigera & $\mathrm{K}$ into $\mathrm{T}$ & & & \\
\hline & 112 & E. hirtiflora & $\mathrm{L}$ into $\mathrm{E}$ & & & \\
\hline & 114 & E. selaginifolia & W into $\mathrm{R}$ & & & \\
\hline & 123 & E. baccans, E. hispidula & $\mathrm{N}$ into I & & & \\
\hline
\end{tabular}




\begin{tabular}{|c|c|c|c|c|c|c|}
\hline Gene & Codon & Branch & $\begin{array}{l}\text { Amino acid } \\
\text { change }\end{array}$ & Property & $\begin{array}{l}\text { Category } \\
\text { of change }\end{array}$ & $\begin{array}{l}\text { Statistical } \\
\text { error }\end{array}$ \\
\hline & 127 & E. baccans & $\mathrm{T}$ into $\mathrm{K}$ & & & \\
\hline & 148 & E. baccans & $\mathrm{N}$ into I & & & \\
\hline \multirow{28}{*}{ rpoC1 } & 42 & E. pseudocalycina & A into $\mathrm{P}$ & \multirow{4}{*}{$\begin{array}{l}\text { Alpha-helical } \\
\text { tendencies }\left(\mathrm{P}_{\alpha}\right)\end{array}$} & \multirow[t]{4}{*}{8} & \multirow[t]{4}{*}{0.050} \\
\hline & 48 & $\begin{array}{l}\text { E. discolor, E.versicolor, } E \text {. } \\
\text { versicolor } 2\end{array}$ & $\mathrm{G}$ into $\mathrm{E}$ & & & \\
\hline & 60 & E. imbricata, E. imbricata 2 & A into $\mathrm{G}$ & & & \\
\hline & 147 & $\begin{array}{l}\text { E. globiceps, E.globiceps } 2, \text { E. } \\
\text { versicolor, E. versicolor } 2\end{array}$ & E into $\mathrm{G}$ & & & \\
\hline & 73 & E. multiflora & $\mathrm{W}$ into $\mathrm{C}$ & \multirow{3}{*}{$\begin{array}{l}\text { Chromatographic } \\
\text { index }\end{array}$} & \multirow[t]{3}{*}{8} & \multirow[t]{3}{*}{0.050} \\
\hline & 98 & E. melanthera & W into $\mathrm{C}$ & & & \\
\hline & 195 & E. coccinea & $\mathrm{F}$ into $\mathrm{C}$ & & & \\
\hline & 133 & E. sessiliflora & $\mathrm{D}$ into $\mathrm{V}$ & $\begin{array}{l}\text { Beta-structure } \\
\text { tendencies }\end{array}$ & 7 & 0.050 \\
\hline & 48 & $\begin{array}{l}\text { E. discolor, E.versicolor, E. } \\
\text { versicolor } 2\end{array}$ & $\mathrm{G}$ into $\mathrm{E}$ & \multirow[t]{2}{*}{ Compressibility } & \multirow[t]{2}{*}{7} & \multirow[t]{2}{*}{0.050} \\
\hline & 147 & $\begin{array}{l}\text { E. globiceps, E.globiceps } 2, \text { E. } \\
\text { versicolor, E. versicolor } 2\end{array}$ & E into $G$ & & & \\
\hline & 73 & E. multiflora & W into $\mathrm{C}$ & \multirow{4}{*}{$\begin{array}{l}\text { Partial specific } \\
\text { volume }\end{array}$} & \multirow[t]{4}{*}{7} & \multirow[t]{4}{*}{0.050} \\
\hline & 98 & E. melanthera & W into $\mathrm{C}$ & & & \\
\hline & 102 & E. coccinea, E. sessiliflora & $\mathrm{R}$ into $\mathrm{G}$ & & & \\
\hline & 197 & E. bauerii & $\mathrm{G}$ into $\mathrm{R}$ & & & \\
\hline & 45 & E. melanthera & $\mathrm{P}$ into $\mathrm{S}$ & \multirow{5}{*}{$\begin{array}{l}\text { Power to be at } \\
\text { the C-terminal }\end{array}$} & \multirow[t]{6}{*}{7} & \multirow[t]{6}{*}{0.050} \\
\hline & 48 & $\begin{array}{l}\text { E. discolor, E.versicolor, E. } \\
\text { versicolor } 2\end{array}$ & $\mathrm{G}$ into $\mathrm{E}$ & & & \\
\hline & 132 & E. vagans & $P$ into $S$ & & & \\
\hline & 133 & E. sessiliflora & $\mathrm{D}$ into $\mathrm{V}$ & & & \\
\hline & 147 & $\begin{array}{l}\text { E. globiceps, E.globiceps } 2, E \text {. } \\
\text { versicolor, E. versicolor } 2\end{array}$ & E into $\mathrm{G}$ & & & \\
\hline & 233 & E. baccans & $\mathrm{E}$ into $\mathrm{K}$ & & & \\
\hline & 118 & E. patersonii, E. vagans & T into I & \multirow{2}{*}{$\begin{array}{l}\text { Solvent } \\
\text { accessible } \\
\text { reduction ratio }\end{array}$} & \multirow[t]{2}{*}{7} & \multirow[t]{2}{*}{0.050} \\
\hline & 133 & E. sessiliflora & $\mathrm{D}$ into $\mathrm{V}$ & & & \\
\hline & 73 & E. multiflora & W into $\mathrm{C}$ & \multirow{4}{*}{$\begin{array}{l}\text { Molecular } \\
\text { volume }\end{array}$} & \multirow[t]{4}{*}{6} & \multirow[t]{4}{*}{0.050} \\
\hline & 98 & E. melanthera & W into $\mathrm{C}$ & & & \\
\hline & 102 & E. coccinea, E. sessiliflora & $\mathrm{R}$ into $\mathrm{G}$ & & & \\
\hline & 197 & E. bauerii & $\mathrm{G}$ into $\mathrm{R}$ & & & \\
\hline & 73 & E. multiflora & $\mathrm{W}$ into $\mathrm{C}$ & \multirow{2}{*}{$\begin{array}{l}\text { Molecular } \\
\text { weight }\end{array}$} & \multirow[t]{2}{*}{6} & \multirow[t]{2}{*}{0.050} \\
\hline & 98 & E. melanthera & $\mathrm{W}$ into $\mathrm{C}$ & & & \\
\hline \multirow[t]{9}{*}{ rpoB } & 108 & $\begin{array}{l}\text { E. regia, E. cinerea2, E. multiflora, } \\
\text { E. imbricata2, E. globiceps } 2, \text { E. } \\
\text { arborea } 2, \text { E. vagans, E. versicolor, } \\
\text { E. versicolor2, E. strigilifolia, } \\
\text { E. sessiliflora, E. patersonii, E. } \\
\text { plukenetii SWO3, E. plukenetii } \\
\text { SWO18, E. plukenetii SWO56, E. } \\
\text { plukenetii2, E. discolor, E. cruenta, } \\
\text { E. curviflora }\end{array}$ & I into $\mathrm{R}$ & Buriedness & 8 & 0.001 \\
\hline & 7 & $\begin{array}{l}\text { E. multiflora, E. arborea, E. } \\
\text { arborea } 2, \text { E. vagans }\end{array}$ & P into $\mathrm{L}$ & Coil tendencies & 8 & 0.050 \\
\hline & 27 & E. regia & $\mathrm{G}$ into $\mathrm{V}$ & & & \\
\hline & 57 & E. bauerii, E. hibbertii, E. vestita & $\mathrm{L}$ into $\mathrm{P}$ & & & \\
\hline & 189 & E. sessiliflora & A into $G$ & & & \\
\hline & 39 & E. cinerea2 & $\mathrm{R}$ into $\mathrm{G}$ & Helical contact & 8 & 0.050 \\
\hline & 103 & E. caffra & $\mathrm{G}$ into $\mathrm{R}$ & area & & \\
\hline & 215 & E. sessiliflora, E. plukenetii 2 & $\mathrm{R}$ into $\mathrm{G}$ & & & \\
\hline & 108 & $\begin{array}{l}\text { E. regia, E. cinerea2, E. multiflora, } \\
\text { E. imbricata } 2, \text { E. globiceps } 2, \text { E. } \\
\text { arborea } 2, \text { E. vagans, E. versicolor, } \\
\text { E. versicolor } 2, \text { E. strigilifolia, } \\
\text { E. sessiliflora, E. patersonii, E. } \\
\text { plukenetii SWO3, E. plukenetii } \\
\text { SWO18, E. plukenetii SWO56, E. } \\
\text { plukenetii2, E. discolor, E. cruenta, } \\
\text { E. curviflora }\end{array}$ & I into $\mathrm{R}$ & Hydropathy & 8 & 0.010 \\
\hline
\end{tabular}




\begin{tabular}{|c|c|c|c|c|c|c|}
\hline Gene & Codon & Branch & $\begin{array}{l}\text { Amino acid } \\
\text { change }\end{array}$ & Property & $\begin{array}{l}\text { Category } \\
\text { of change }\end{array}$ & $\begin{array}{l}\text { Statistical } \\
\text { error }\end{array}$ \\
\hline & 215 & E. regia & $\mathrm{R}$ into $\mathrm{L}$ & & & \\
\hline & 7 & $\begin{array}{l}\text { E. multiflora, E. arborea, } E \text {. } \\
\text { arborea } 2, \text { E. vagans }\end{array}$ & P into $\mathrm{L}$ & $\begin{array}{l}\text { Power to be at } \\
\text { the C-terminal }\end{array}$ & 8 & 0.050 \\
\hline & 57 & E. bauerii, E. hibbertii, E. vestita & L into $\mathrm{P}$ & & & \\
\hline & 7 & $\begin{array}{l}\text { E. multiflora, E. arborea, E. } \\
\text { arborea } 2, \text { E. vagans }\end{array}$ & P into $\mathrm{L}$ & $\begin{array}{l}\text { Power to be at } \\
\text { the N-terminal }\end{array}$ & 8 & 0.001 \\
\hline & 57 & E. bauerii, E. hibbertii, E. vestita & L into $\mathrm{P}$ & $\left(a_{n}\right)$ & & \\
\hline & 7 & $\begin{array}{l}\text { E. multiflora, E. arborea, E. } \\
\text { arborea } 2, \text { E. vagans }\end{array}$ & P into $\mathrm{L}$ & Compressibility & 7 & 0.001 \\
\hline & 15 & E. floccifera & $\mathrm{E}$ into $\mathrm{G}$ & & & \\
\hline & 57 & E. bauerii, E. hibbertii, E. vestita & L into $\mathrm{P}$ & & & \\
\hline & 197 & E. cinerea 2 & $\mathrm{G}$ into $\mathrm{E}$ & & & \\
\hline & 39 & E. cinerea2 & $\mathrm{R}$ into $\mathrm{G}$ & Molecular & 7 & 0.050 \\
\hline & 103 & E. caffra & $\mathrm{G}$ into $\mathrm{R}$ & weight & & \\
\hline & 215 & E. sessiliflora, E. plukenetii2 & $\mathrm{R}$ into $\mathrm{G}$ & & & \\
\hline & 5 & E. globiceps & $\mathrm{I}$ into $\mathrm{T}$ & Solvent & 7 & 0.001 \\
\hline & 19 & E. selaginifolia & $\mathrm{T}$ into I & accessible & & \\
\hline & 108 & $\begin{array}{l}\text { E. regia, E. cinerea } 2, \text { E. multiflora, } \\
\text { E. imbricata } 2, \text { E. globiceps } 2, \text { E. } \\
\text { arborea } 2, \text { E. vagans, E. versicolor, } \\
\text { E. versicolor } 2, \text { E. strigilifolia, } \\
\text { E. sessiliflora, E. patersonii, E. } \\
\text { plukenetii SWO3, E. plukenetii } \\
\text { SWO18, E. plukenetii SWO56, E. } \\
\text { plukenetii } 2, \text { E. discolor, E. cruenta, } \\
\text { E. curviflora }\end{array}$ & I into $\mathrm{R}$ & reduction ratio & & \\
\hline & 14 & E. hirtiflora & $\mathrm{M}$ into $\mathrm{R}$ & Total non- & 7 & 0.001 \\
\hline & 84 & E. globiceps & Q into L & bonded energy & & \\
\hline & 108 & $\begin{array}{l}\text { E. regia, E. cinerea } 2, \text { E. multiflora, } \\
\text { E. imbricata } 2, \text { E. globiceps } 2, \text { E. } \\
\text { arborea } 2, \text { E. vagans, E. versicolor, } \\
\text { E. versicolor } 2, \text { E. strigilifolia, } \\
\text { E. sessiliflora, E. patersonii, E. } \\
\text { plukenetii SWO3, E. plukenetii } \\
\text { SWO18, E. plukenetii SWO56, E. } \\
\text { plukenetii } 2, \text { E. discolor, E. cruenta, } \\
\text { E. curviflora }\end{array}$ & I into R & & & \\
\hline & 215 & E. regia & $\mathrm{R}$ into $\mathrm{L}$ & & & \\
\hline & 7 & $\begin{array}{l}\text { E. multiflora, E. arborea, E. } \\
\text { arborea } 2, \text { E. vagans }\end{array}$ & P into $\mathrm{L}$ & Turn tendencies & 7 & 0.010 \\
\hline & 9 & E. bauerii, E. vestita & $\mathrm{S}$ into $\mathrm{L}$ & & & \\
\hline & 15 & E. floccifera & E into $G$ & & & \\
\hline & 57 & E. bauerii, E. hibbertii, E. vestita & L into $\mathrm{P}$ & & & \\
\hline & 189 & E. sessiliflora & A into $G$ & & & \\
\hline & 197 & E. cinerea2 & $\mathrm{G}$ into $\mathrm{E}$ & & & \\
\hline & 201 & E. regia & L into $\mathrm{S}$ & & & \\
\hline & 7 & $\begin{array}{l}\text { E. multiflora, E. arborea, } E \text {. } \\
\text { arborea } 2, \text { E. vagans }\end{array}$ & P into $\mathrm{L}$ & $\begin{array}{l}\text { Alpha-helical } \\
\text { tendencies }\end{array}$ & 6 & 0.050 \\
\hline & 14 & E. plukenetii SWO56 & $\mathrm{M}$ into $\mathrm{T}$ & & & \\
\hline & 57 & E. bauerii, E. hibbertii, E. vestita & $\mathrm{L}$ into $\mathrm{P}$ & & & \\
\hline & 90 & E. newdigate & A into $\mathrm{T}$ & & & \\
\hline & 5 & E. globiceps & I into $\mathrm{T}$ & Average number & 6 & 0.001 \\
\hline & 7 & $\begin{array}{l}\text { E. multiflora, E. arborea, E. } \\
\text { arborea } 2, \text { E. vagans }\end{array}$ & P into $\mathrm{L}$ & $\begin{array}{l}\text { of surrounding } \\
\text { residues }\end{array}$ & & \\
\hline & 9 & E. bauerii, E. vestita & $\mathrm{S}$ into $\mathrm{L}$ & & & \\
\hline & 19 & E. selaginifolia & $\mathrm{T}$ into $\mathrm{I}$ & & & \\
\hline & 57 & E. bauerii, E. hibbertii, E. vestita & L into $\mathrm{P}$ & & & \\
\hline & 84 & E. globiceps & Q into $\mathrm{L}$ & & & \\
\hline & 108 & $\begin{array}{l}\text { E. regia, E. cinerea } 2, \text { E. multiflora, } \\
\text { E. imbricata } 2, \text { E. globiceps } 2, \text { E. } \\
\text { arborea } 2, \text { E. vagans, E. versicolor, } \\
\text { E. versicolor } 2, \text { E. strigilifolia, } \\
\text { E. sessiliflora, E. patersonii, E. } \\
\text { plukenetii } S W O 3, \text { E. plukenetii }\end{array}$ & I into $\mathrm{R}$ & & & \\
\hline
\end{tabular}




\begin{tabular}{|c|c|c|c|c|c|c|}
\hline Gene & Codon & Branch & $\begin{array}{l}\text { Amino acid } \\
\text { change }\end{array}$ & Property & $\begin{array}{l}\text { Category } \\
\text { of change }\end{array}$ & $\begin{array}{l}\text { Statistical } \\
\text { error }\end{array}$ \\
\hline & & $\begin{array}{l}\text { SWO18, E. plukenetii SWO56, E. } \\
\text { plukenetii2, E. discolor, E. cruenta, } \\
\text { E. curviflora }\end{array}$ & & \multirow{10}{*}{$\begin{array}{l}\text { Isoelectric point } \\
(\mathrm{pHi})\end{array}$} & \multirow{10}{*}{6} & \multirow{10}{*}{0.001} \\
\hline & 201 & E. regia & L into $\mathrm{S}$ & & & \\
\hline & 215 & E. regia & $\mathrm{R}$ into $\mathrm{L}$ & & & \\
\hline & 39 & E. cinerea2 & $\mathrm{R}$ into $\mathrm{G}$ & & & \\
\hline & 101 & $\begin{array}{l}\text { E. arborea2, E. cinerea2, E. } \\
\text { coccinea, E. curviflora, E. cruenta, } \\
\text { E. discolor, E. globiceps, E. } \\
\text { imbricata } 2, \text { E. mammosa, E. } \\
\text { melanthera, E. multiflora, E. } \\
\text { patersonii, E. plukenetii SWO3, E. } \\
\text { plukenetii SWO18, E. plukenetii } \\
\text { SWO56, E. plukenetii2, E. regia, } \\
\text { E. sessiliflora, E. strigilifolia, } \\
\text { E. vagans, E. versicolor, E. } \\
\text { versicolor } 2, \text { E. vestita }\end{array}$ & $\mathrm{T}$ into $\mathrm{K}$ & & & \\
\hline & 103 & E. caffra & $\mathrm{G}$ into $\mathrm{R}$ & & & \\
\hline & 108 & $\begin{array}{l}\text { E. regia, E. cinerea2, E. multiflora, } \\
\text { E. imbricata2, E. globiceps } 2, \text { E. } \\
\text { arborea } 2, \text { E. vagans, E. versicolor, } \\
\text { E. versicolor } 2, \text { E. strigilifolia, } \\
\text { E. sessiliflora, E. patersonii, E. } \\
\text { plukenetii SWO3, E. plukenetii } \\
\text { SWO18, E. plukenetii SWO56, E. } \\
\text { plukenetii } 2, \text { E. discolor, E. cruenta, } \\
\text { E. curviflora }\end{array}$ & I into $\mathrm{R}$ & & & \\
\hline & 122 & E. cinerea2 & $\mathrm{K}$ into $\mathrm{Q}$ & & & \\
\hline & 214 & E. patersonii & $\mathrm{K}$ into $\mathrm{N}$ & & & \\
\hline & 215 & E. sessiliflora, E. plukenetii2 & $\mathrm{R}$ into $\mathrm{L}$ & & & \\
\hline & $\begin{array}{l}84 \\
108\end{array}$ & $\begin{array}{l}\text { E. globiceps } \\
\text { E. regia, E. cinerea2, E. multiflora, } \\
\text { E. imbricata2, E. globiceps } 2, \text { E. } \\
\text { arborea2, E. vagans, E. versicolor, } \\
\text { E. versicolor } 2, \text { E. strigilifolia, } \\
\text { E. sessiliflora, E. patersonii, E. } \\
\text { plukenetii SWO3, E. plukenetii } \\
\text { SWO18, E. plukenetii SWO56, E. } \\
\text { plukenetii2, E. discolor, E. cruenta, } \\
\text { E. curviflora }\end{array}$ & $\begin{array}{l}\text { Q into L } \\
\text { I into } R\end{array}$ & $\begin{array}{l}\text { Mean r.m.s. } \\
\text { fluctuation } \\
\text { displacement }\end{array}$ & 6 & 0.050 \\
\hline & 14 & E. hirtiflora & M into $\mathrm{R}$ & \multirow[t]{2}{*}{ Polarity } & \multirow[t]{2}{*}{6} & \multirow[t]{2}{*}{0.001} \\
\hline & 108 & $\begin{array}{l}\text { E. regia, E. cinerea } 2, \text { E. multiflora, } \\
\text { E. imbricata2, E. globiceps } 2, \text { E. } \\
\text { arborea2, E. vagans, E. versicolor, } \\
\text { E. versicolor } 2, \text { E. strigilifolia, } \\
\text { E. sessiliflora, E. patersonii, E. } \\
\text { plukenetii SWO3, E. plukenetii } \\
\text { SWO18, E. plukenetii SWO56, E. } \\
\text { plukenetii2, E. discolor, E. cruenta, } \\
\text { E. curviflora }\end{array}$ & I into $\mathrm{R}$ & & & \\
\hline & 5 & E. globiceps & I into $\mathrm{T}$ & \multirow{5}{*}{$\begin{array}{l}\text { Surrounding } \\
\text { hydrophobicity }\end{array}$} & \multirow[t]{5}{*}{6} & \multirow[t]{5}{*}{0.001} \\
\hline & 7 & $\begin{array}{l}\text { E. multiflora, E. arborea, } E \text {. } \\
\text { arborea } 2, \text { E. vagans }\end{array}$ & P into $\mathrm{L}$ & & & \\
\hline & 19 & E. selaginifolia & $\mathrm{T}$ into I & & & \\
\hline & 57 & E. bauerii, E. hibbertii, E. vestita & L into $\mathrm{P}$ & & & \\
\hline & 108 & $\begin{array}{l}\text { E. regia, E. cinerea2, E. multiflora, } \\
\text { E. imbricata2, E. globiceps } 2, \text { E. } \\
\text { arborea } 2, \text { E. vagans, E. versicolor, } \\
\text { E. versicolor2, E. strigilifolia, } \\
\text { E. sessiliflora, E. patersonii, E. } \\
\text { plukenetii SWO3, E. plukenetii } \\
\text { SWO18, E. plukenetii SWO56, E. } \\
\text { plukenetii2, E. discolor, E. cruenta, } \\
\text { E. curviflora }\end{array}$ & I into $\mathrm{R}$ & & & \\
\hline
\end{tabular}




\begin{tabular}{|c|c|c|c|c|c|c|}
\hline Gene & Codon & Branch & $\begin{array}{l}\text { Amino acid } \\
\text { change }\end{array}$ & Property & $\begin{array}{l}\text { Category } \\
\text { of change }\end{array}$ & $\begin{array}{l}\text { Statistical } \\
\text { error }\end{array}$ \\
\hline & 27 & E. cinerea, E. cinerea 2 & G into D & \multirow{5}{*}{$\begin{array}{l}\text { Total non- } \\
\text { bonded energy }\end{array}$} & \multirow[t]{5}{*}{6} & \multirow[t]{5}{*}{0.010} \\
\hline & 39 & E. cinerea2 & $\mathrm{R}$ into $\mathrm{G}$ & & & \\
\hline & 101 & $\begin{array}{l}\text { E. arborea } 2, \text { E. cinerea } 2, \text { E. } \\
\text { coccinea, E. curviflora, E. cruenta, } \\
\text { E. discolor, E. globiceps, E. } \\
\text { imbricata } 2, \text { E. mammosa, E. } \\
\text { melanthera, E. multiflora, E. } \\
\text { patersonii, E. plukenetii SWO3, } \\
\text { E.plukenetii SWO18, E. plukenetii } \\
\text { SWO56, E. plukenetii2, E. regia, } \\
\text { E. sessiliflora, E. strigilifolia, } \\
\text { E. vagans, E. versicolor, E. } \\
\text { versicolor } 2, \text { E. vestita }\end{array}$ & $\mathrm{T}$ into $\mathrm{K}$ & & & \\
\hline & 103 & E. caffra & $\mathrm{G}$ into $\mathrm{R}$ & & & \\
\hline & 215 & E. sessiliflora, E. plukenetii2 & $\mathrm{R}$ into $\mathrm{G}$ & & & \\
\hline \multirow[t]{23}{*}{ rpoA } & 50 & E. pseudocalycina & $\mathrm{E}$ into $\mathrm{G}$ & \multirow{4}{*}{$\begin{array}{l}\text { Alpha-helical } \\
\text { tendencies }\end{array}$} & \multirow[t]{4}{*}{8} & \multirow[t]{4}{*}{0.050} \\
\hline & 67 & E. floccifera, E. plumigera & G into A & & & \\
\hline & 181 & E. ampullaceae & $\mathrm{P}$ into $\mathrm{A}$ & & & \\
\hline & 237 & E. umbelliflora & $\mathrm{G}$ into $\mathrm{E}$ & & & \\
\hline & 13 & E. tetralix & W into $\mathrm{G}$ & \multirow[t]{3}{*}{ Bulkiness } & \multirow[t]{3}{*}{8} & \multirow[t]{3}{*}{0.010} \\
\hline & 19 & E. umbelliflora & $\mathrm{V}$ into $\mathrm{G}$ & & & \\
\hline & 189 & E. imbricata & $\mathrm{V}$ into $\mathrm{G}$ & & & \\
\hline & 19 & E. umbelliflora & $\mathrm{V}$ into $\mathrm{G}$ & \multirow[t]{5}{*}{ Coil tendencies } & \multirow[t]{5}{*}{8} & \multirow[t]{5}{*}{0.010} \\
\hline & 67 & E. floccifera, E. plumigera & $\mathrm{G}$ into $\mathrm{A}$ & & & \\
\hline & 181 & E. ampullaceae & $\mathrm{P}$ into $\mathrm{A}$ & & & \\
\hline & 189 & E. imbricata & V into $\mathrm{G}$ & & & \\
\hline & 239 & E. hispidula, E. versicolor 2 & $\mathrm{P}$ into $\mathrm{L}$ & & & \\
\hline & 44 & E. hispidula & $\mathrm{R}$ into $\mathrm{L}$ & Hydropathy & 8 & 0.050 \\
\hline & 13 & E. tetralix & W into $\mathrm{G}$ & $\begin{array}{l}\text { Molecular } \\
\text { volume }\end{array}$ & 8 & 0.050 \\
\hline & 13 & E. tetralix & W into $\mathrm{G}$ & $\begin{array}{l}\text { Molecular } \\
\text { weight }\end{array}$ & 8 & 0.050 \\
\hline & 13 & E. tetralix & $\mathrm{W}$ into $\mathrm{G}$ & $\begin{array}{l}\text { Partial specific } \\
\text { volume }\end{array}$ & 8 & 0.050 \\
\hline & 82 & E. umbelliflora & $\mathrm{H}$ into $\mathrm{P}$ & \multirow{3}{*}{$\begin{array}{l}\text { Power to be at } \\
\text { the C-terminal }\end{array}$} & \multirow{4}{*}{8} & \multirow[t]{4}{*}{0.001} \\
\hline & 176 & $\begin{array}{l}\text { E. cruenta, E. discolor, } E . \\
\text { hispidula, E. patersonii, } E . \\
\text { plumigera, E. sessiliflora, } E . \\
\text { tetralix, E. versicolor }\end{array}$ & $\mathrm{H}$ into $\mathrm{P}$ & & & \\
\hline & 211 & $\begin{array}{l}\text { E. ampullaceae, E. arborea2, E. } \\
\text { cinerea, E. cinerea } 2, \text { E. coccinea, } \\
\text { E. curviflora, E. floccifera, E. } \\
\text { globiceps, E. globiceps } 2, E . \\
\text { imbricata, E. imbricata } 2, E . \\
\text { melanthera, E. multiflora, E. } \\
\text { patersonii, E. plukenetii SWO3, E. } \\
\text { plukenetii SWO18, E. plukenetii } \\
\text { SWO56, E. plukenetii2, E. } \\
\text { pseudocalycina, E. selaginifolia, E. } \\
\text { vagans, E. versicolor } 2\end{array}$ & P into $\mathrm{H}$ & & & \\
\hline & 239 & E. hispidula, E. versicolor 2 & P into L & & & \\
\hline & 82 & E. umbelliflora & $\mathrm{H}$ into $\mathrm{P}$ & \multirow{3}{*}{$\begin{array}{l}\text { Power to be at } \\
\text { the middle of } \\
\text { alpha-helix }\left(\mathrm{a}_{\mathrm{m}}\right)\end{array}$} & \multirow[t]{3}{*}{8} & \multirow[t]{3}{*}{0.001} \\
\hline & 176 & $\begin{array}{l}\text { E. cruenta, E. discolor, } E \text {. } \\
\text { hispidula, E. patersonii, } E \text {. } \\
\text { plumigera, E. sessiliflora, } E \text {. }\end{array}$ & $\mathrm{H}$ into $\mathrm{P}$ & & & \\
\hline & 211 & $\begin{array}{l}\text { tetralix, E. versicolor } \\
\text { E. ampuflaceae, E. arborea } 2, E . \\
\text { cinerea, E. cinerea } 2, \text { E. coccinea, } \\
\text { E. curviflora, E. floccifera, E. } \\
\text { globiceps, E. globiceps } 2, E . \\
\text { imbricata, E. imbricata } 2, E . \\
\text { melanthera, E. multiflora, E. } \\
\text { patersonii, E. plukenetii SWO3, E. } \\
\text { plukenetii SWO18, E. plukenetii }\end{array}$ & P into $\mathrm{H}$ & & & \\
\hline
\end{tabular}




\begin{tabular}{|c|c|c|c|c|c|c|}
\hline Gene & Codon & Branch & $\begin{array}{l}\text { Amino acid } \\
\text { change }\end{array}$ & Property & $\begin{array}{l}\text { Category } \\
\text { of change }\end{array}$ & $\begin{array}{l}\text { Statistical } \\
\text { error }\end{array}$ \\
\hline & & $\begin{array}{l}\text { SWO56, E. plukenetii2, } E \text {. } \\
\text { pseudocalycina, E. selaginifolia, } \\
\text { E. vagans, E. versicolor } 2\end{array}$ & & & & \\
\hline & 13 & E. tetralix & $\mathrm{W}$ into $\mathrm{G}$ & Refractive index & 8 & 0.050 \\
\hline & 44 & E. hispidula & $\mathrm{R}$ into $\mathrm{L}$ & $\begin{array}{l}\text { Chromatographic } \\
\text { index }\end{array}$ & 7 & 0.050 \\
\hline & 136 & E. pseudocalycina & C into $\mathrm{R}$ & Composition & 7 & 0.050 \\
\hline & 151 & $\begin{array}{l}\text { E. coccinea, E. imbricata, } E \text {. } \\
\text { imbricata } 2\end{array}$ & C into $\mathrm{R}$ & (C) & & \\
\hline & 50 & E. pseudocalycina & $\mathrm{E}$ into $\mathrm{G}$ & Compressibility & 7 & 0.001 \\
\hline & 82 & E. umbelliflora & $\mathrm{H}$ into $\mathrm{P}$ & & & \\
\hline & 176 & $\begin{array}{l}\text { E. cruenta, E. discolor, E. } \\
\text { hispidula, E. patersonii, E. } \\
\text { plumigera, E. sessiliflora, } E . \\
\text { tetralix, E. versicolor }\end{array}$ & $\mathrm{H}$ into $\mathrm{P}$ & & & \\
\hline & 211 & $\begin{array}{l}\text { E. ampullaceae, E. arborea2, E. } \\
\text { cinerea, E. cinerea2, E. coccinea, } \\
\text { E. curviflora, E. floccifera, E. } \\
\text { globiceps, E. globiceps } 2, E . \\
\text { imbricata, E. imbricata } 2, E . \\
\text { melanthera, E. multiflora, E. } \\
\text { patersonii, E. plukenetii SWO3, E. } \\
\text { plukenetii SWO18, E. plukenetii } \\
\text { SWO56, E. plukenetii2, E. } \\
\text { pseudocalycina, E. selaginifolia, E. } \\
\text { vagans, E. versicolor } 2\end{array}$ & P into $\mathrm{H}$ & & & \\
\hline & 237 & E. umbelliflora & $\mathrm{G}$ into $\mathrm{E}$ & & & \\
\hline & 239 & E. hispidula, E. versicolor 2 & $\mathrm{P}$ into $\mathrm{L}$ & & & \\
\hline & 28 & E. tetralix & $\mathrm{S}$ into $\mathrm{R}$ & Isoelectric point & 7 & 0.050 \\
\hline & 19 & E. umbelliflora & V into $\mathrm{G}$ & Mean r.m.s. & 7 & 0.001 \\
\hline & 82 & E. umbelliflora & $\mathrm{H}$ into $\mathrm{P}$ & fluctuation & & \\
\hline & 176 & $\begin{array}{l}\text { E. cruenta, E. discolor, E. } \\
\text { hispidula, E. patersonii, E. } \\
\text { plumigera, E. sessiliflora, } E . \\
\text { tetralix, E. versicolor }\end{array}$ & $\mathrm{H}$ into $\mathrm{P}$ & displacement & & \\
\hline & 211 & $\begin{array}{l}\text { E. ampullaceae, E. arborea2, E. } \\
\text { cinerea, E. cinerea2, E. coccinea, } \\
\text { E. curviflora, E. floccifera, E. } \\
\text { globiceps, E. globiceps } 2, E . \\
\text { imbricata, E. imbricata } 2, E . \\
\text { melanthera, E. multiflora, E. } \\
\text { patersonii, E. plukenetii SWO3, E. } \\
\text { plukenetii SWO18, E. plukenetii } \\
\text { SWO56, E. plukenetii2, E. } \\
\text { pseudocalycina, E. selaginifolia, E. } \\
\text { vagans, E. versicolor } 2\end{array}$ & P into $\mathrm{H}$ & & & \\
\hline & 216 & E. imbricata & $\mathrm{M}$ into $\mathrm{K}$ & & & \\
\hline & 239 & E. hispidula, E. versicolor 2 & $\mathrm{P}$ into $\mathrm{L}$ & & & \\
\hline & 160 & $\begin{array}{l}\text { E. globiceps, E. globiceps } 2, \text { E. } \\
\text { tetralix, }\end{array}$ & $\mathrm{T}$ into $\mathrm{A}$ & $\begin{array}{l}\text { Alpha-helical } \\
\text { tendencies }\end{array}$ & 6 & 0.050 \\
\hline & 168 & E. strigilifolia & $\mathrm{M}$ into $\mathrm{T}$ & & & \\
\hline & 182 & E. cinerea, $E$. cinerea2 & A into $\mathrm{T}$ & & & \\
\hline & 203 & E. regia & $\mathrm{T}$ into $\mathrm{A}$ & & & \\
\hline & 239 & E. hispidula, E. versicolor 2 & P into $\mathrm{L}$ & & & \\
\hline & 43 & E. globiceps 2 & I into $\mathrm{T}$ & Buriedness & 6 & 0.050 \\
\hline & 216 & E. imbricata & $\mathrm{M}$ into $\mathrm{K}$ & & & \\
\hline & 13 & E. tetralix & W into $\mathrm{G}$ & Chromatographic & 6 & 0.050 \\
\hline & 60 & E. multiflora, E. tetralix & $\mathrm{F}$ into $\mathrm{S}$ & index & & \\
\hline & 216 & E. imbricata & $\mathrm{M}$ into $\mathrm{K}$ & & & \\
\hline & 31 & E. umbelliflora, E. melanthera & $\mathrm{N}$ into $\mathrm{K}$ & Isoelectric point & 6 & 0.050 \\
\hline & 44 & E. hispidula & $\mathrm{R}$ into $\mathrm{L}$ & & & \\
\hline & 71 & E. cinerea, E. cinerea2 & $\mathrm{K}$ into $\mathrm{T}$ & & & \\
\hline & 198 & E. versicolor 2 & $\mathrm{~T}$ into $\mathrm{K}$ & & & \\
\hline & 222 & E. caffra & $\mathrm{K}$ into $\mathrm{Q}$ & & & \\
\hline
\end{tabular}

